\title{
Silicon in soils, plants and its important role in crop production: A review
}

\author{
${ }^{1}$ El-Sayed A.A., ${ }^{2}$ Abou Seeda M.A., ${ }^{2}$ Yassen A.A., ${ }^{2}$ Sahar M. Zaghloul and ${ }^{2}$ A. Khater \\ ${ }^{1}$ Fertilization Technology Dept., ${ }^{2}$ Plant Nutrition Dept., National Research Centre, 33 El Buhouth St., \\ (Former El Tahrir St.) 12622 Dokki, Giza, Egypt.
} Received: 18 June 2019/ Accepted 17 Sept. 2019 / Publication date: 15 Oct. 2019

\begin{abstract}
Silicon in soil solution is present as silicic acid, at concentrations normally ranging from 0.1 to $2.0 \mathrm{mM}$, roughly two orders of magnitude higher than the concentrations of phosphorus. Cropping system cannot allow for recycling Silicon element by plants. The decrease of bioavailable-Si may have significant impacts on cereal crops. The assumption of the depletion of plant available-Si is still admissible, but new conspicuous have proven that phytoliths are a significant source of Silicon for plant. Plants uptake silicon in silicic acid form. Silicon concentrations vary greatly in plant aboveground parts, ranging from 0.1 to $10.0 \% \mathrm{SiO}_{2}$ of dry weight basis or even higher. The difference in Si accumulation attributed to the ability of the roots to take up Si. It is obvious that most of the effects of Si were expressed through Si deposition on the leaves, stems, and hulls. In spite of Si has not been proven to be an essential element for higher plants, it is a beneficial element for the healthy growth and development and even productivity of many crop species, particularly for rice which contains about $10 \% \mathrm{SiO}_{2}$ in shoots on a dry weight basis. The beneficial effects of $\mathrm{Si}$ are particularly distinct in plants exposed to biotic or abiotic stress. Silicon is effective in controlling various pests and diseases caused by both fungi and bacteria in different plant species. Silicon also exerts alleviative effects on various abiotic stresses including salt stress, metal toxicity, drought stress, radiation damage, nutrient imbalance, high temperature, freezing and so on. Also, Silicon has been widely reported to alleviate the plant water status and water balance, especially under various stress conditions in both monocot and dicot plants Numerous research studies showing that the application of Si enhances the tolerance of some plant species to toxic metals, including manganese Mn, zinc $\mathrm{Zn}$ aluminum $\mathrm{Al}$, cadmium $\mathrm{Cd}$ and arsenic As. In addition, studies have shown that Si alleviates growth inhibition and oxidative damage.
\end{abstract}

Keywords: Silicon, soil, plant, depletion, ability, crop production.

\section{1-Introduction}

Silicon $\mathrm{Si}$ is the second most abundant element in soil. In soil solution, Si occurs mainly as monosilicic acid $\mathrm{H}_{4} \mathrm{SiO}_{4}$ at concentrations ranging from 0.1 to $0.6 \mathrm{mM}$, roughly two orders of magnitude higher than the concentrations of phosphorus in soil solutions and is taken up by plants in this form of silicic acid Ma and Takahashi (2002); Snyder et al., (2007) and Bogdan and Schenk(2008),Epstein(1999) Keeping et al.,(2009), After Si uptake, it accumulates on the epidermis of various tissues mainly as a polymer of hydrated amorphous silica. All terrestrial plants contain Si in their tissues although the content of Si varies considerably with the species, ranging from 0.1 to $10 \%$ $\mathrm{Si}$ on a dry weight basis Ma and Takahashi (2002) and Hodson et al., (2005). This gives rise to additional confusion, as the beneficial properties of $\mathrm{Si}$ are generally linked to the amount absorbed by the plant Ma, (2004). However, silicon Si is not an essential element for plant growth, development and productivity Liang and Sun, (2007) and Manivannan et al. (2016). Although, it plays an important beneficial role in many crops, especially for Si-accumulating plants under abiotic and biotic stress conditions. The major reason is that there is no evidence to show that $\mathrm{Si}$ is involved in the metabolism of plant, which is one of the three criteria required for essentiality established by Richmond and Sussman, (2003). Recently, essential elements that are essential for plant growth and productivity is defined by Epstein and Bloom (2003) as: 1 the element is part of a molecule which is an intrinsic component of the structure or metabolism of the plant, and 2 the plant can be so severely deficient in the element that it exhibits abnormalities in growth, development, or reproduction. According to this

Corresponding Author: Abou Seeda M.A., Plant Nutrition Dept., National Research Centre, 33 El Buhouth St., (Former El Tahrir St.) 12622 Dokki, Giza, Egypt.

E-mail:mabouseeda@gmail.com 
definition, $\mathrm{Si}$ is considered to be an essential element for higher plants because Si deficiency causes various abnormalities in the plant, as reported by many authors Ma and Takahashi, (2002).

Plants taken up $\mathrm{Si}$ from the soil solution as monosilicic acid $\mathrm{H}_{4} \mathrm{SiO}_{4}$, which distributed to the cell wall and epidermis. Consequently, promotes an increase in cell wall stiffness, and provides better leaf architecture. It may also improve photosynthetic capacity in some plant species, increase plant resistance to disease and pest attack, and reduce transpiration, enhancing water use efficiency WUE by the plant Korndörfer et al., (2002); Ma (2004) and Rodrigues et al., (2011).The amount of silicon and its distribution in soils is greatly affected by soil parent material, the climatic condition, soil texture, and intensity of soil weathering. Silicon can be lost during the soil weathering process, and the remaining in the soil is in a polymerized form and not available to plants. Furthermore, Si diminution in the soil can be occur due to intensive cultivation practices, in addition to Si-depletion due to the extensive use of phytosanitary and NPK fertilizers for maintaining sustainable agriculture. for that reason many soils are generally low in available Si Meena et al.,(2014).Low availability of silicon appear in soils of tropical areas. In such soils, the response of cultivated crops to silicon fertilization is clear, and improving yield of some crops, especially Si accumulators plants, such as rice and sugar cane Pereira et al., (2007). Si fertilization can improve crop yields and bring other benefits to plants such as increasing plant tolerance to abiotic and biotic stresses. Silicate fertilization in some countries such as Japan, the USA, South Africa, and China is a common practices, especially for rice, sugar cane, pasture and corn crops, which accumulate large amounts of the element in their tissues; however, recently, research with other crops, such as soybeans, beans, eucalyptus, potatoes, and others, have shown promising results Currie and Perryl (2007). Many researchers mentioned that, Si- fertilization is a simple and sustainable way to help maintain and enhance plant health and productivity Datnoff and Rodrigues, (2015) and Taiz et al., (2013).

Many studies have attempted to phenotype and classify plants according to their ability to absorb Silicon Hodson et al., (2005); Trembath- Reichert et al., (2015), a difficult endeavor considering the numerous factors that can influence the data. With novel experimental techniques, the advancement of genomics and developments such as the discovery of Si transporters, new opportunities are available to characterize accumulator and non-accumulator plants based on specific molecular features. In this review, the role of $\mathrm{Si}$ in conferring resistance to multiple stresses is described.

\section{2-Silicon in soil: content, form and availability}

Silicon is the seventh most abundant element in the universe and the second most abundant element on the planet, after oxygen, making about 28 percent of the Earth's crust Datnoff et al. (2001). Total Si content in soil ranges normally from 25 to $35 \%$ with an average of $30 \%$, depending greatly upon soil types and weathering. However, in some highly weathered soils such as latosols or latosolic red soils in the tropics where desilification and fersialitization processes are extremely active, Si content can be as low as less than $1 \%$. Si content and its availability in soil depend greatly upon soil-forming processes and consequently soil types Sommer et al. (2006).

$\mathrm{Si}$ content and its availability in soil depend greatly upon soil-forming processes and consequently soil types. Soil Si-poolscan be existed in two either mineral which may occur in primary minerals inherited from parent material or biogenic pools through formation a secondary minerals such as clay minerals, Sommer et al.,(2006). Silicon dioxide $\mathrm{SiO}_{2}$, is the most abundant mineral in soils which is part of the structure of most clay minerals Barbosa et al., (2001). During soil weathering process, esilicatization occurs, which decreases the Si content of the soil, and is basically present in the form of opal, quartz $\mathrm{SiO}_{2} \cdot \mathrm{nH}_{2} \mathrm{O}$, and other forms not available to plants; therefore, the soil may be high in insoluble Si and very low in plant-available Si Barbosa et al.,(2001) . However, total silicon in soils is not a good indicator for availability of silicon to plant growth as mentioned byBerthelsen and, Korndörfer, (2012).

In soil, monosilicic acid $\mathrm{H}_{4} \mathrm{SiO}_{4}$ is the most available form of $\mathrm{Si}$ in soils solution, at concentrations normally ranging from 0.1 to $0.6 \mathrm{mM}$, Tubana et al.,(2016); Epstein (1994), most of which is not dissociated $\mathrm{pK} 1=9.6$, an aspect that makes the element more readily available to plants, Raven, (1983). However, rapid polymerization of monosilicic acid $\mathrm{H}_{4} \mathrm{SiO}_{4}$ gradually occur at high concentrations of silicon, with increasing soil $\mathrm{pH}$, and in the presence of oxides and hydroxides of aluminum and iron, Berthelsen and Korndörfer (2002). Thus, Si concentration in the soil solution is a 
dynamic process and influenced by its stability and dissolution of primary and secondary minerals at the solid phase, phytogenic cycling of $\mathrm{Si}$, soil $\mathrm{pH}$, organic matter, $\mathrm{Si}$ adsorption/desorption onto $\mathrm{Fe} / \mathrm{Al}$ hydrous oxide surfaces and Si-uptake by plants and microorganisms, Meyer (2001); Cornelis et al (2011); Haynes (2014) and Tubana et al., (2016).

Available Si in soils refers to the amount of Si that can be taken up by plants during the growing season and is usually considered an index for soil Si-supplying capacity. Generally, Si is absorbed and transported by plants in the form of monosilicic acid $\mathrm{H}_{4} \mathrm{SiO}_{4}$. Thus, available Si in soils include monosilicic acid in soil solution and parts of silicate components that can be easily converted into monosilicic acids such as polymerized silicic acid, exchangeable silicates and part of colloidal silicates. At $\mathrm{pH}$ values $2-9$, especially at physiological $\mathrm{pH}$ values, $\mathrm{Si}$ in soil is mainly present as monosilicic acid and converted to monosilicic acid into ionic silicates at $\mathrm{pH}>9$. The main factors influencing $\mathrm{Si}$ availability in soil or Si-supplying power capacity include types of soil and parent material, historical land-use change, soil $\mathrm{pH}$, soil texture, soil $\mathrm{Eh}$, organic matter, temperature and accompanying ions Husnain et al.,(2008); Struyf et al.,(2010a,b) .

Silicon availability and supplying power vary with soil types, depending mainly on the type of parent materials, weathering and eluviation and illuviation. Soils derived from granite, quartz porphyry and peat are prone to Si deficiency, while, those developed from basalt and volcanic ash contain sufficient Silicon. The paddy soils which are subjected to intensive weathering and eluviation are prone to Si deficiency, whereas those which are subjected to slight weathering and eluviation are generally rich in plant-available Si. In terms of Si availability, Li et al., (1999), classified soils into three categories. The first: is the soils derived from granite, quartzite and alluvial deposits. These soils are sandy with strong leaching capacity, had lowest contents of available Si; ranging from 33.3 to 43.3 $\mathrm{mg} \mathrm{SiO}_{2} \mathrm{~kg}^{-1}$. They reported that 94 to $100 \%$ of the tested soil samples are Si deficient or severely Si deficient. The second category: is the soils developed from red sandstone, pelite, lacustrine deposits and quaternary red earth. These soils, mainly due to desilification and fersialitization, had lower average available Si content, ranging from 52.9 to $66.7 \mathrm{mg} \mathrm{SiO}_{2} \mathrm{~kg}^{-1}$ and 80 to $85 \%$ of these soils are deficient or severely deficient in Si. The third category: is the soils derived from purple rock, limestone and Xiashu loess. These soils had higher available $\mathrm{Si}$ content due to their clayey soil texture, ranging from 98 to $125.8 \mathrm{mg} \mathrm{SiO}_{2} \mathrm{~kg}^{-1}$ and only 33 to $60 \%$ of these soils are Si deficient. The available Si content varied with soil type in a descending order of paddy soils $>$ brown soils $>$ limestone soils > cinnamon soils Dai et al., (2008). Intense biogeochemical cycling of silica occurs in soils Blecker et al., (2006); Gérard et al., (2008). It is reported that the annual ecosystem biogeochemical cycling of Si exceeds the annual export from continents to the ocean by two orders of magnitude Conley, (2002); Struyf et al., (2010a) .

Many studies have shown that soils with light or sandy texture are usually deficient in available $\mathrm{Si}$ and thus have low Si-supplying power, while those with heavy or clayey texture are Si sufficient, Cai et al. (1997); Gérard et al., (2008) and Li et al. (2012). Soil-available Si content is positively correlated with clay content in soils Wang et al. (2004) ; Gérard et al., (2008) ; Dai et al. (2004) as soil clay minerals with high specific surface have a high capacity to adsorb silicate.

Numerous studies show that soil-available Si content is closely positively correlated with soil pH values Kawaguchi and Kyuma (1977) Husnain et al.,(2008); Haynes (2014); Ma et al. (2008) ; Berthelsen and,Korndörfer (2012); Liang et al.(1994); Shen et al.(2014); He and Li (1995); Husnain et al., (2008); Haynes (2014) and Tubana et al., (2016); Cai et al.(1997); Struyf et al.,(2010,b); Li et al. 1999; Struyf et al.,(2010 a).The concentration of monosilicic acid is strongly dependent upon soil $\mathrm{pH}$. The lowest concentration of monosilicic acid is observed at $\mathrm{pH} 8-9$, below or above which the concentration of monosilicic acid $\mathrm{H}_{4} \mathrm{SiO}_{4}$ increases significantly. Si concentration in soil solution may rise sharply when $\mathrm{pH}$ value decreases from 7 to 2 (Berthelsen and Korndörfer (2012).

\section{3-Silicon in plants}

Despite the abundant benefits of silicon in agriculture, it is generally not considered as an essential plant element. In nature, silicon occurs as the oxide silica and as silicates, in which it is used in fertilizers. Epstein and Bloom, (2003) .Plant assimilates silicon through roots as silicic acid. Inside plant, it travels to active growing points, where it complexes with an organic compound in the cell walls and make them stronger. The beneficial effects of Si on plants have been demonstrated by many studies using pots, hydroponic, and field experiments. Silicon enhances growth and yield of all annual 
and vegetable crops, promotes upright growth stronger and thicker stems, shorter internodes, prevents lodging, promotes favorable exposure of leaves to light, provides resistance to bacterial and fungal diseases and decrease some abiotic stress as temperatures, salinity, heavy metal and aluminum toxicity.

They concluded that Si concentration in plant ashes varied according to plant species, with higher concentrations in Gramineae., with large variability, ranging from $0.1 \%$ to $10 \%$ dry weight Epstein (1999); Hodson et al.,(2005). Generally, monocots are richer in silicon than Dicots, with some exceptions. Sangster et al. (2001) indicate that the following families show silicification processes: Among monocots: Cyperaceae e.g., sedge and Gramineae e.g., wheat Even if significant levels of Si are found in very different plants, and among dicots: some Fabaceae e.g., pea, Cucurbitaceae e.g., cucumber, Rosales e.g., elm, and Asteraceae e.g. sunflower. Sangster (1978) and Hodson et al. (2005) consider that Si concentration in plants depends primarily on the phylogenetic position of the plant, more than on its environment i.e., Si concentration in the soil and the soil solution, $\mathrm{pH}$. Ma and Takahashi (2002), propose criteria to differentiate non-accumulating plants from accumulating plants: a "Accumulator plants" have a Si concentration over $1 \%$ and a $[\mathrm{Si}] /[\mathrm{Ca}]$ ratio $>1$. b" Excluder plants" have a Si concentration below $0.5 \%$ and a $[\mathrm{Si}] /[\mathrm{Ca}]$ ratio, c "intermediates plants" that do not meet these criteria. In addition, there are large differences among genotypes within the same species Deren, (2001). Several data compilations have reported the extent of this variation Hodson et al. (2005); Ma and Takahashi (2002). However, a given species or cultivar grown in various Si concentrations will absorb different amounts of $\mathrm{Si}$, as shown in banana, rice, or tomato Henriet et al.,(2006); $\mathrm{Ma}$ and Takahashi (2002).

Regarding the essentiality of Si-element in plants nutrition, in two corn plants with different $\mathrm{Si}$ concentration in their shoot ashes; $0.3 \%$ and $9 \%$, respectively, there was no difference in their growth as observed by Sachs 1862. Therefore, he concluded that Si was not an essential for plant growth. The essentiality of Si for plants had not been proven because of the difficulty to remove entirely Si from experimental nutrient solutions and thus obtain control plants. He suggested Si to be "quasi-essential for many of those plants for which its absolute essentiality has not been established." Since the reviews by Epstein (1994), (1999), many studies have been conducted on the mechanisms of Si uptake, transport, and accumulation in plants that are useful to discuss the concept of Si essentiality.

The essentiality of $\mathrm{Si}$ in plant nutrition was first highlighted by Sachs 1862. He observed no differences in the growth of two corn plants in spite that $\mathrm{Si}$ reached $0.3 \%$ and $9 \% \mathrm{Si}$ in their shoot ashes, respectively, therefore, he concluded that Si was not essential. In 1906, the question of the role of $\mathrm{Si}$ in plants, doubting that an element forming up to $60 \%$ of the wheat ash had no metabolic role was raised. More recently, Epstein (1994) stated that the non-essentiality of Si is difficult to be proven because of the difficulty to remove entirely Si from experimental nutrient solutions and thus obtain control plants. He suggested Si to be "quasi-essential for many of those plants for which its absolute essentiality has not been established."

According to science researches, silicon increase plant's resistance to many plant diseases such as powdery mildew, septoria and eye-spot and also many insect pests. Silicon has positive effect on the biomass yield under deficit irrigation. Plants subjected to draught, treated with silicon, maintained higher stomatal conductivity, relative water content and water potential. It helps leaves become larger and thicker, thus limiting the loss of water through transpiration and reduces water consumption.

Although all terrestrial plants contain some silicon $\mathrm{Si}$ in their tissues, the concentration of $\mathrm{Si}$ in shoots varies greatly among plant species from 0.1 to $10 \% \mathrm{Si}$ on a dry weight basis, showing an extremely uneven distribution within the plant kingdom Ma et al. (2001a); Richmond and Sussman,(2003). In higher plants Angiospermae, only few taxa show high $>4 \% \mathrm{Si}$; Cyperaceae, Poaceae and Balsaminaceae to moderate $2-4 \% \mathrm{Si}$; Cucurbitales, Urticales and Commelinaceae Si accumulation Ma and Takahashi (2002); Hodson et al.,(2005) .

In agronomy, silicon is not a limiting factor in soils. Plants greatly differ in their ability to take up silicon from soil. crops such as sugar cane can take up silicon as much as $300 \mathrm{~kg} \mathrm{ha}^{-1}$ year ${ }^{-1}$ Meyer and Keeping, 2001 and $500 \mathrm{~kg} \mathrm{ha}^{-1}$ year ${ }^{-1}$ for rice Makabe et al.(2009) comparing with 41-67 kg ha year ${ }^{-1}$ for tropical forests Lucas et al.,(1993); Alexandre et al.,(1997), 22-67 kg ha year $^{-1}$ for US grasslands Blecker et al.(2006), and 2.3-44 $\mathrm{kg} \mathrm{ha}^{-1}$ year $^{-1}$ for temperate forests Bartoli (1983); Gérard et al.(2008); Cornelis et al.(2010). There is also a genotypic variation in the shoot Si concentration, although the variation within species is usually much lower than the variation among species grown 
under the same conditions, rice Oryza sativa contains $39 \mathrm{mg} \mathrm{Si} \mathrm{g}^{-1}$ in the shoots, but chickpea Cicer arietinum contains only $3.0 \mathrm{mg} \mathrm{Si} \mathrm{g}{ }^{-1}$ Berthelsen and Korndörfer (2012).

On the other hand, the Si concentration in barley Hordeum vulgare grain showed a smaller variation, ranging from 1.2 to $3.8 \mathrm{mg} \mathrm{Si} \mathrm{g}{ }^{-1} \mathrm{Ma}$ et al. 2004 . In sugarcane Saccharum officinarum, the Si concentration in the shoots varied with the cultivars, ranging from 6.4 to $10.2 \mathrm{mg} \mathrm{Si} \mathrm{g}{ }^{-1}$ Deren (2001) . In rice Oryza sativa, japonica cultivars usually showed a higher Si concentration than indica cultivars Ma et al. (2008).

In general, the difference in Si accumulation of different plant species has been attributed to the specific potential of roots to take up Si Ma and Yamaji (2006). Plants take up Si in the form of the monomeric, uncharged molecule of orthosilicic acid $\mathrm{H}_{4} \mathrm{SiO}_{4}$, as the only molecular species likely to cross the root plasma membrane at physiological pH Raven (2001). Passive transport of uncharged monosilicic acid by diffusion across the lipid component of the plasma membrane and/or by facilitated diffusion via proteinaceous channels is an energy-independent component of Si uptake, which is present in all plant species regardless of their ability to accumulate -Si Raven, (2003). However, a metabolically active, energy-dependent component of Si transport has been identified in various Si-accumulating species both high accumulators and intermediate plants including rice, barley, maize Zea mays, wheat Triticum aestivum, banana Musa sp., and cucumber Cucumis sativus, Tamai and Ma (2003) ; Henriet et al.(2006) ; Liang et al.(2005) ; Liang et al.(2006) ; Nikolic et al.(2007).

\section{1-Silicon uptake by roots:}

$\mathrm{pH}$ of soil solution and natural waters is generally less than 9.5, under such condition, Silicon is chiefly present as uncharged monomeric orthosilicic acid, $\mathrm{H}_{4} \mathrm{SiO}_{4}$ Casey et al.(2004), with concentrations ranged between 0.1 to $0.6 \mathrm{mM}$ Epstein (1994). Wonisch et al.(2008). Côté-Beaulieu et al. (2009) reported that in soil solutions of acidic condition particularly in humid countries soils, however, minor but significant up to $20 \%$ of total Si concentrations of polymerized silicic acid have been observed supplied wheat with organic compounds as methyl silanols that proved to be toxic. Therefore, it appears that orthosilicic acid remains the main form of Silicon absorbed by roots, although Fu et al. (2002) suggested that root uptake might occur via physical incorporation of Si soil particles. The mechanisms of Silicon uptake have been studied in rice, a Silicon accumulator. Estimating the permeability of the plasma membrane at $10-10 \mathrm{~m} \cdot \mathrm{s}^{-1}$, Raven 2001 reported that high concentrations of Silicon presented in rice, this phenomenon could not due to a simple flow caused by the permeability of the membrane and that the absorption of Silicon required a metabolic control.

Rains et al. (2006) proposed a metabolic control as Silicon uptake in wheat is constrained by either dinitrophenol or potassium cyanide. They also decided that the mechanisms complicated in Silicon uptake by wheat, rice, or other species are similar, "differences being a matter of degree" and leading to various Silicon concentrations in plants. Using a mutant cultivar that excludes $\mathrm{Si}$, Ma et al. (2004) isolated two Silicon transporters: one called $\mathrm{S}_{\mathrm{I}} \mathrm{T}_{1}$, responsible for the radial transport of Silicon from the external solution to the cortical cells, and the other called $\mathrm{S}_{\mathrm{T}} \mathrm{T}_{2}$, responsible for the transporters work oppositely to the concentration gradient, suggesting processes that consume energy. Also using rice mutants, Ma et al. (2001a) showed lateral roots, but not root hairs perform that Silicon uptake. Since this pioneer work on rice, Si influx transporters have been identified in maize Mitani et al. (2009), but not in wheat yet. Active and passive uptakes can coexist within the same plant (Henriet et al., 2006; Mitani and Ma (2005); Ding et al., 2008; Liang et al., (2007); Gérard et al.,(2008). For example, Henriet et al. (2006) they studded the Silicon uptake by bananas grown in hydroponics at different concentrations of Silicon. On the other hand, at higher Silicon supplies, absorption of silicon was proportional to the mass flow-driven supply, in good agreement with a passive uptake. At lower supplies of silicon, the absorption was larger than the one expected if mass flow-driven supply had been the only mechanism, and Silicon in the nutrient solution was depleted, suggesting an active uptake.

\section{2- Silicon translocation to shoots}

Silicon is transferred to the shoots through the penetrating the xylem. Transpiration is important factor regulating transport and deposition of Silicon in plant shoots. Generally, concentration of Silicon in plant is directly reflects its rate of transpiration. Raven (2001), Henriet et al.(2006) 
investigated that concentrations of silicon in several parts of banana grown in hydroponic culture with deferent concentration of silicon, found, that concentration gradient within the plant reflects the major role of transpiration in Silicon transport and this, whatever the Silicon concentration in solution. Silicon isotope studies have been proven, useful to evidence the role of transpiration.

In rice, Ding et al. (2008) found enrichment in the heavier isotope $\mathrm{Si}^{30}$ from roots, to stem and leaves, then husk and grains that is well explained by the Rayleigh distillation law. Leng et al.(2009) have recently reviewed the potential use of Si isotopes in plants. As transpiration is the main driver for Silicon transport and deposition, the duration of plant growth plays an important role in the Si concentration, older leaves of a plant are richer in Si than younger ones Henriet et al.(2006). Besides all the evidences, which demonstrate the role of transpiration, Mitani et al.(2009), have isolated a gene that mainly functions as a Si transporter for xylem uploading in maize. More work is therefore required to elucidate the importance of active vs. passive transfer of Si to the shoots.

\section{3- Silicon accumulation in shoots}

Casey et al. (2004) observed that in wheat sap, the only forms of Silicon present were monoand di-silicic acids, with a ratio of 7:1. Nevertheless, this part of soluble Silicon is minimal as compared with the solid form. Sangster et al. (2001) studied the distribution of Silicon in a wheat plant during its growth. After 8 or 10 days, Silicon was almost exclusively found as a solid form in the aerial parts. Indicated that Silicon is quickly precipitates as amorphous silica. Lux et al. (2003) observed that after only two hour, formation of silica aggregates in the root endodermis of a sorghum plant were occurred and transfer from a Si-poor environment to a Si-rich environment.

The presence of organo-silicon compounds in plants is not formally established. Inanaga et al. (1995) suggested that in rice, Silicon plays a role in the formation of links between lignin and carbohydrates, in association with phenolic acids. Nevertheless, there is no evidence of a $\mathrm{Si}-\mathrm{C}$ bond, and the instability of $\mathrm{Si}-\mathrm{O}-\mathrm{C}$ bonds at physiological $\mathrm{pH}$, suggests that $\mathrm{Si}$ is probably regulated differently from the other nutrients Perry and Keeling (1998). Amorphous silica is therefore virtually the only form of Silicon in plants Ding et al. (2008). Amorphous silica particles that precipitate in plant cells are called Phytoliths. Phytoliths may contain impurities such as Al, Fe, Ti, Mn, P Cu, N, and accumulated Clarke (2003), but are usually near stoichiometric silica Dietrich et al. 2003, the formula of which is $\left[\mathrm{SiO}_{n} \mathrm{OH} 2 n-4\right]_{\mathrm{m}}$ with $n<2$ and $m$ large. Phytoliths can be accumulated without any energy by polymerization of silicic acid when its concentration exceeds $2 \mathrm{mM}$ Ma and Yamaji (2006). Proportions and locations of Phytoliths vary with the species, but also with the age of the plant Ponzi and Pizzolongo (2003), Sangster et al. (2001). Phytoliths are not found evenly throughout the plant Ponzi and Pizzolongo (2003); Prychid et al. (2003); Sangster et al. (2001), but in leaf epidermis, in root endodermis, and in cell membranes of the vascular bundle in relation with sclerenchyma at transpiration sites. In the case of wheat, Silicon is present in all tissues with higher levels in the inner tangential and radial walls of endodermis cells Bouzoubaa (1991). In the leaves, Silicon is at first preferentially deposited in the abaxial epiderm, and then in both epiderms as the leaf grows Hodson and Sangster (1988). Among those tissues, phytoliths are found in specific cells called silica cells located on vascular bundles and/or are present as silica bodies in bulliform cells, fusoid cells or prickle hairs in rice Ma and Yamaji (2006), wheat Dietrich et al. (2003), or bamboos Motomura et al. 2004. These specific allocations observed in Poaceae have been taken both as proofs of passive or active Si transport, depending on the allocation Motomura et al. (2004).

The amount of silicon accumulated by plants is therefore a significant parameter in the natural functioning of soil development and in controlling the continental erosion rates. In agronomy, silicon is generally not considered an essential element, it is also currently assumed that Silicon is not limiting in soils. However, crops particularly for sugar cane can take up silicon as much as $300 \mathrm{~kg}$ $\mathrm{ha}^{-1}$ year ${ }^{-1}$ Meyer and Keeping 2001 and $500 \mathrm{~kg} \mathrm{ha}^{-1}$ year $^{-1}$ for rice Makabe et al.(2009) comparing with 41-67 kg ha ${ }^{-1}$ year $^{-1}$ for tropical forests Lucas et al.(1993); Alexandre et al.(1997), 22-67 kg $\mathrm{ha}^{-1}$ year $^{-1}$ for US grasslands Blecker et al.(2006), and 2.3-44 $\mathrm{kg} \mathrm{ha}^{-1}$ year $^{-1}$ for temperate forests Bartoli (1983); Gérard et al.( 2008); Cornelis et al.(2010). Matichenkov and Bocharnikova (2001) calculated that 210-224 million tons of Silicon are removed from cultivated soil every year. This figure is of the same order of magnitude as the annual flux of dissolved silica from rivers to oceans Berner and Berner (1996) shows that agriculture may have a significant impact at a global scale. 
Savant et al. (1997a) suggested that the non-re incorporation of the straw to the field might lead to a depletion of plant-available Silicon in soils with a decline of cereal yields.

\section{4- Role of Si in alleviation of a biotic and biotic stress}

The positive role of silicon on the alleviation of abiotic and biotic stress is now well recognized. However, it was generally considered that Si had little or no effect on plant metabolism under optimum growth conditions Ma, (2004). The beneficial effects of Si in improving plant tolerance against diseases and pests are described by numerous researchers. Wang et al. (2004) provides a catalog of many significant studies and discusses models explaining the role of $\mathrm{Si}$ in plant tolerance against stress conditions. For a long time, Si-derived resistance to pathogens and insects was thought to be the result of a mechanical barrier formed by the deposition of Si along the cell wall thus hindering their progression. However, studies performed in the 90's associated the presence of $\mathrm{Si}$ with specific defense responses in planta Chérif et al.,(1992, 1994); Fawe et al.,(1998), a phenomenon that has since been shown in many host-pathogen interactions Fauteux et al., (2005). In a recent study, Vivancos et al. (2015) found that Si was further $\mathrm{n}$ to interfere with host-pathogen recognition, probably by preventing effectors and signaling molecules from finding their specific targets. Silicon was also suggested to induce indirect defense mechanisms by altering the composition of herbivoreinduced plant volatiles HIPV Liu et al., (2009). The HIPV compounds play an important role in attracting parasitoids to infested rice plants. The list of studies reporting prophylactic effects of $\mathrm{Si}$ against diseases grow continuously but the underlying molecular mechanisms explaining these properties are not yet fully understood. Nevertheless, these studies offer additional support to explore $\mathrm{Si}$ as an environmental-friendly option for sustainable crop management.

Rather the direct impact of Si extends to more fundamental metabolic processes. Fauteux et al. (2005) found that in the absence of stress, Si application altered regulation of only two genes in Arabidopsis thaliana. Though this species does not actively accumulate Si Vivancos et al., (2015), beneficial effects of $\mathrm{Si}$ in this model plant have been demonstrated Ghanmi et al., (2004); Fauteux et al., (2006). Recent pot-based experiments on the impact of $\mathrm{Si}$ application on sugarcane Saccharum spp. hybrid growth and defense against an insect herbivore revealed significant increases in plant growth even in the absence of herbivory Vivancos et al., (2015). In wheat, Derry, et al. (2005) found that $\mathrm{Si}$ amendment affected the regulation of 47 genes in unstressed plants, while Brunings et al. (2009) reported the altered regulation of 221 genes in unstressed rice plants, of which 28 were associated with defense and stress, while the remainder were associated with primary metabolic processes or had unknown functions. In rice, Van Bockhaven et al. (2015) found that Si altered the expression of genes associated with cell wall biosynthesis and glycolysis, and down regulated nitrogen and amino acid metabolism, as well as the metabolism of the ethylene, JA and SA defense hormones.

There is a great debate about the importance of silicon in plant nutrition. However, its beneficial and important role for the productivity of some crops, especially when exposed to stress factors cannot neglected. It can be said, until now, this role is limited to defense - defense against the factors of biotic and abiotic stress.

\section{1- Defense mechanisms}

There are two proposed hypotheses for the Si-enhanced resistance of plants to diseases and pests: First: Physical one where, Si deposited on the tissue surface acts as a physical barrier. It prevents physical penetration and / or makes the plant cells less susceptible to enzymatic degradation by fungal pathogens. This mechanism is supported by the positive correlation between the Si content and the degree of suppression of diseases and pests. The physical defense features include structures such as thorns, spines, trichomes, raphides, rough, tough epidermal cells, and hard shells and pods. Many plants armor themselves with solid hydrated amorphous silica, or opal, incorporated in cell walls. There is ample evidence for the protection that silicon often provides plant species against insect pests. Reinforcement of the cell wall by deposition of solid silica in them is one of the ways in which this protection is effected. Currie and Perry (2007) have discussed the bio mineralization of silicon. We have studied this deposition of silicon in the cell wall of wheat leaves and awns Rafi et al., (1997). The silica in trichomes lends leaves and awns the roughness and the toughness that impede the penetration of herbivores and pathogens through the cell walls. It acts as a physical 
barrier. That, then, is one of the means by which silicon defends plants subject to attack. Second: where, Si functions as a signal to induce the production of phytoalexin Cherif et al., (1994). Si application to cucumber resulted in the stimulation of the chitinase activity and rapid activation of peroxidases and polyphenoloxidases after infection with Pythium spp. Glycosidically bound phenolics extracted from Si-treated plants when subjected to acid or,B-glucosidase hydrolysis displayed a strong fungistatic activity. However, in oat attacked by Blumeria graminis, Si deficiency promoted the synthesis of phenolic compoundsCarver et al. (1998). The phenylalanine ammonia-lyase activity was enhanced by Si deficiency. The reason why Si deficiency exerts opposite effects on the synthesis of phenolic compounds, as a disease response in different plant species, has not been elucidated.

Moreover, Kauss et al. (2003) reported that during the induction of systemic all acquired resistance SAR in cucumber, the expression of a gene encoding a novel proline-rich protein was enhanced. This protein has C-terminal repetitive sequences containing an unusually high amount of lysine and arginine. This synthetic peptide was able to polymerize orthosilicic acid to insoluble silica, which is known to be involved in cell wall reinforcement, at the site of the attempted penetration of fungi into epidermal cells. Several potential mechanisms associated with Si and stress alleviation in higher plants have been identified through one of the following defenses systems:-

\subsection{1-Physical defense mechanism}

An increased physical barrier produced by Si deposition beneath leaf cuticles has long been considered to represent a major component underlying silicon-mediated plant resistance to insect pests. Massey et al. (2007), reported that Si deposition contributes to increased rigidity and abrasiveness of plant tissues, thereby forming a mechanical barrier and reducing their palatability and digestibility to both vertebrate. Silicon deposition increased abrasiveness of leaves and reduces food quality for herbivores and may cause wear of herbivore mouthparts, which further reduces feeding efficiency and growth rates Massey et al. (2007), On the other hand, using a simple method to determine mandibular wear Smith et al.(2007), it was shown that although there was a trend for increased wear in Eldana saccharina larvae that developed on silicon-treated sugarcane, the ability of larvae to renew their mandibles at each moult probably allows them to compensate for increased wear Kvedaras et al.(2010). Controversy, it was found that, ground wollastonite $\mathrm{CaSiO}_{3}$ in artificial diets at rates of up to $3.3 \%$ silicon had no significant effect on larval growth of Helicoverpa armigera Hübner; Lepidoptera: Noctuidae and Helicoverpa punctigeraWallengren, suggesting that silicon may not be directly deleterious to insects via ingestion and other mechanisms may be involved in silicon-mediated plant resistance Stanley et al.,(2014). It should be noted, however, that by grinding the silicon, this has likely removed potential abrasive attributes, in addition to the potential effects of soluble-silicon-induced plant defenses.

The physical features include structures such as thorns, spines, trichomes, raphides, rough, tough epidermal cells, and hard shells and pods. Many plants armor themselves with solid hydrated amorphous silica, or opal, incorporated in cell walls. There is ample evidence for the protection that silicon often provides plant species against insect pests. Reinforcement of the cell wall by deposition of solid silica in them is one of the ways in which this protection is effected. Currie and Perry (2007) have discussed the bio mineralization of silicon. We have studied this deposition of silicon in the cell wall of wheat leaves and awns Rafi et al., (1997)

The joint use of scanning electron micrography and $\mathrm{X}$ ray microanalysis of the same trichomes showed the localization of silica in the trichomes; none could be detected in the trichomes of plants grown in minus-silicon solutions. The silica in trichomes lends leaves and awns the roughness and the toughness that impede the penetration of herbivores and pathogens through the cell walls. It acts as a physical barrier. That, then, is one of the means by which silicon defends plants subject to attack.Using energy-dispersive X-ray EDX and X-ray mapping, it was shown that the pattern of silicon deposition in sugarcane, especially at the internode and root band, is likely the reason for increased resistance of silicon-treated sugarcane to penetration and feeding by E. saccharina at these sites Keeping et al., (2009). Further, epidermal silicon was higher in the control i.e., no silicon treatment, E. saccharina resistant cultivar, than the susceptible control cultivar, suggesting that such differences in silicon-mediated resistance exist to a large extent due to the varying ability of cultivars to deposit silicon within the stalk epidermis Keeping et al.(2009), thus preventing $E$. saccharina penetration Kvedaras et al., (2010). A more recent study using scanning electron 
microscopy and EDX compared four grass species, and showed that spine and phytolith morphology both within and between species may be more important than leaf silicon concentration in determining the abrasiveness and/or digestibility of leaves and thus the effectiveness of anti-herbivore defense Hartley et al.,(2015). The authors showed that all tested grasses were able to deposit new types of silicon-based structures due to increasing silicon supply. Such changes were particularly evident when the leaves were mechanically damaged; however, damage in the absence of additional silicon did not produce such structures Hartley et al., (2015).

\subsubsection{Biochemical defense mechanisms}

Hartmann (2008), has traced the early development of ideas concerning biochemical defenses that have evolved in the plant kingdom. The early studies were made in the $19^{\text {th }}$ century but then largely forgotten until the mid-20 $0^{\text {th }}$ century. McNaughton and Tarrants (1983) showed that plants growing in a more heavily mammal-grazed grassland in the Serengeti, Tanzania, accumulated more silica in their leaf blades relative to plants from a less heavily grazed site, and blade silica content was higher when plants were defoliated, suggesting that silicification is an inducible defense system against mammalian herbivores. In a laboratory study, Massey et al. (2007) demonstrated, that feeding by both a mammal, M. agrestis and an insect, Schistocerca gregaria Forskal Orthoptera: Acrididae led to increased levels of silica in grass leaves. Other recent studies on arthropods have demonstrated that silicon-mediated anti-herbivore defense is both inducible and allele chemical-mediatedGomes et al.,(2005); Kvedaras et al.,(2010); Costa et al., (2011) and these effects can complement the physical effects described above, leading to impaired feeding, growth, and development Increasing evidence shows that silicon treatment increases transcript levels of defense-related genes, thereby enhancing the activities of plant defensive enzymes Liang et al.,(2003); Cai et al.,(2008); Rahman et al., (2015) and consequently increasing accumulation of some defensive compounds, such as phenolics, phytoalexins, and momilactones Fawe et al.,(1998); Rodrigues et al., (2004); Rémus et al., (2005).Furthermore, Gomes et al.,(2005) showed that the addition of silicon strongly enhanced wheat resistance to green bug Schizaphis graminum Rondani; Hemiptera: Aphididae. In addition, silicon pre-treatment increased the activities of the defensive enzymes polyphenoloxidase, peroxidase, and phenylalanine ammonia lyase. In particular, silicon facilitated the strongest resistance if wheat plants to aphids. In this contexet, Chérif et al.(1994) found that silicon-treated cucumber plants show remarkable increases in the activity of enzymes peroxidase, polyphenoloxidase, $\beta-1,3$ glucanase, and chitinase in response to infection by pathogens. Further,Rahman et al.(2015) found that perennial ryegrass Lolium perenne L. grown in silicon-amended soil exhibited greater activity of peroxidase and polyphenoloxidase, higher levels of several phenolic acids, including chlorogenic acid and flavonoids, and enhanced expression levels of genes encoding phenylalanine ammonia lyase PALa and PALb and lipoxygenase LOXa in response to infection by Magnaporthe oryzae T.T. Hebert M.E. Barr. Histological and ultrastructural analyses revealed that silicon mediates active localized cell defenses, and epidermal cells of silicon-treated plants displayed specific defense reactions including papilla formation, production of callose, and accumulation of glycosilated phenolics in response to pathogen infection by the fungus Blumeria graminis f. sp. tritici DC. speer Bélanger et al.,(2003). It was also found that Silicon-mediated brown spot resistance in rice plants is independent of the classic immune hormones, salicylic acid and jasmonic acid Van Bockhaven et al., (2015). They also found that silicon mounted rice resistance to the brown spot fungus Cochliobolus miyabeanus by interfering with the production and/or action of fungal ethylene, prevents the fungus from suppressing the rice innate immune system.

Recently, it was found that pre-treatment of plants with certain chemicals just prior to biotic stressor may provoke a specific physiological state in plants called "priming" (Fauteux et al., 2006; Hao et al.,(2012); Worrall et al., (2012); Aimé et al.,(2013). Primed plants are thus physiologically ready to induce quicker and/or stronger defense responses upon subsequent attack, providing plants with a more effective means to respond to kind of attack Ton et al.,(2006); Jung et al., (2009); Slaughter et al., (2012); Ye et al.,(2013). A recent study demonstrates that silicon is able to prime jasmonate-mediated defense responses and rice defense against a chewing herbivore, the rice leaffolder, Cnaphalocrocis medinalis Lepidoptera, Pyralidae; Ye et al., (2013). More interestingly, activation of jasmonate signaling in turn promotes silicon accumulation in rice leaves, indicating a 
strong interaction between silicon and jasmonate in rice defense against insect herbivores. Some recent studies have shown that silicon can also prime plants for alleviating biotic stress imposed by pathogens Ghareeb et al.,(2011; Rahman et al.,(2015). Also, Vivancos et al. (2015) showed that priming is also an important mechanism of silicon-mediated resistance of Arabidopsis thaliana $\mathrm{L}$. Heynh. against powdery mildew caused by Golovinomyces cichoracearum DC.. Further, this work has also revealed that silicon may interfere with effector proteins released by such bio trophic pathogens, suggesting that mechanisms other than salicylic acid-dependent plant defense priming are involved. It has been suggested that priming of plant defense responses, alterations in phytohormone homeostasis, and interaction with defense signaling components are all potential mechanisms involved in regulating silicon-triggered resistance responses Van Bockhaven et al., (2013). Silicon has also been demonstrated to prime plants for resistance against abiotic stresses Ahmed et al., (2013). Research on silicon-mediated herbivore resistance lags far behind that on silicon-mediated disease resistance. Further studies are needed to determine the exact nature of silicon-primed anti-herbivore defense and indeed other mechanisms that may play a role in plant resistance to biotic stressors. For example, factors that modulate plant defenses against insects attack have been identified in the saliva of insects Hogenhout and Bos, (2011) and similar mechanism might be proposed for plant pathogens, although this remains to be elucidated.

Recent study regarding the understanding of molecular mechanisms controlling silicon accumulation and the discovery of silicon transporters Deshmukh and Bélanger, (2015) have enabled to classify a plant as Si-competent, or not. This will enable a better understanding of the role of silicon in several fundamental aspects of ecology concerning plant fitness under different stress conditions.

\section{Silicon and water uptake:}

Silicon Si has been widely reported to alleviate the plant water deficit and water balance, especially under various abiotic stress conditions in both monocot and dicot plants, especially under drought and salt stresses. Silicon plays a vital role in regulating leaf transpiration, and involved in the adjustment of root hydraulic conductance by up-regulating aquaporin gene expression and concentrating potassium element in the xylem sap. Many studies support the conclusion that $\mathrm{Si}$ application improves plant water status by increasing root water uptake, rather than by decreasing their water loss under conditions of water deficiency. The enhancement of plant water uptake by Si is achievable through the activation of osmotic adjustment, improving aquaporin activity and increasing the root/shoot ratio. During water deficiency, the regulation of root water uptake, in some cases, may be more crucial to overcome stress injury than the regulation of leaf water loss Aime et al., (2013). Fewer studies have focused on the impact of Si on root water uptake capacity which represented by root hydraulic conductance Taiz et al., (2013). Improving root hydraulic conductance due to Si application has been demonstrated in sorghum Hattori et al.,(2005); Liang et al.,(2015); Liu et al.,(2009), rye Hattori et al.,(2003), tomato Shi et al.,(2005), and cucumber Wang et al., (2004); Zhang, et al.,(2013) under drought stress, salt stress and potassium deficiency conditions. The extent of root hydraulic conductance depends on the driving force, root surface area, root anatomy, and root's permeability to water Taiz et al, (2013); Liang et al., (2015) ); Zhang, et al.,(2006). Various studies has been demonstrated that $\mathrm{Si}$ application promote osmotic driving force. Taiz et al., (2013) suggested that Si application leads to a strong water potential gradient through accumulation of soluble sugars and amino acids in the plant. A similar outcome was observed in rice Cornelis et al (2010). and canola Liu et al. (2012) under drought stress in sorghum, Liu et al. (2009) reported that Si had no effect on osmotic potential of root xylem sap under osmotic stress although it increased root hydraulic conductance. In addition, in tomato grown under osmotic stress, water stress did not cause any change in root osmotic potential in Si-treated plants Shi et al., (2005). Under salt stress, Zhang et al. (2013) found that Si decreased root xylem osmotic potential via accumulation of soluble sugars in cucumber. Under $\mathrm{K}$ deficiency condition, $\mathrm{Si}$ was also seen to decrease the root xylem osmotic potential through accumulation of $\mathrm{K}$ in sorghum Liang et al., (2015) Therefore, under those conditions, regulation of the osmotic driving force could play a central role in Si-mediated enhancement of water uptake.

In addition to driving force, aquaporin were reported to play a pivotal role in regulating root water permeability in response to short term water stress Cornelis et al. (2010). Li et al. (2012) firstly reported that Si-pretreatment significantly increased the expression of aquaporin genes, which in turn 
increased the root water uptake in sorghum under drought stress. Recently, Liu et al. (2012) Cornelis et al. (2010). Li et al. (2012) also observed that $\mathrm{Si}$ application increased aquaporin expression in sorghum and cucumber under salt stress. In addition, Si can also increase aquaporin expression in sorghum under $\mathrm{K}$ deficiency Chen et al., (2009). However, the expression of aquaporin genes; SIPIP1; 3, SIPIP1; 5, and SIPIP2; 6were not regulated by Si application in tomato grown under water stress (Shi et al., 2005). It is worth note that only three aquaporin genes SIPIP1; 3, SlPIP1; 5, and SIPIP2; 6 were studied in this tomato study. Furthermore, modulation of aquaporin transport activity can also occur at post-transcriptional level. Li et al., (2012); Shi et al.,(2005), mentioned that there is expectations that increased root hydraulic conductance by Si under stress conditions may be ascribed to Si-induced reductions in oxidative stress and membrane damage. Similarly, Li et al. (2012), suggested that $\mathrm{Si}$ could enhance aquaporin activity by reducing $\mathrm{H}_{2} \mathrm{O}_{2}$ accumulation, is involved in Si-induced enhancement of root hydraulic conductance under stress conditions. However, the mechanism for the enhancement of root hydraulic conductance under stress conditions still requires further study.

When plants subjected to long period of water stress, changes in root surface and anatomy is important for enhancing plant water uptake Jung et al. (2009). Under drought stress, Si-pretreatment found to increase the root/shoot ratio, contributing to a higher ability of water uptake in sorghum Hattori et al., (2003), (2005). The increased root/shoot ratio was also observed in other studies executed by Ahmed et al.(13,) on sorghum and by Ming et al., 2012 on rice, under drought stress as well as cucumber under salt stress Rodrigues et al., (2011). These results suggest that Si-mediated modifications of root growth may also account for the increase in the water uptake ability in Si-treated plants. However, Li et al. (2012) did not find any Si-mediated changes in vessel diameter or vessel number of sorghum root under drought stress. It might be concluded that, Si-mediated modification of root growth may enhance root water uptake under stress conditions, but this adjustment is not a common phenomenon to all plant species and it remains unclear whether Si is directly involved in the modification of root growth or not. Further studies are needed to clarify how Si regulates root development under water deficient condition.

\section{Silicon and nutrients uptake:}

\section{1- Regulation of nutrient uptake}

Phosphorus: The relationship between silicon and P- absorption by plants from soil was early studied by Eneji et al., (2008), Cheng (1982)They found that Si fertilization significantly increased the grain yields of barley crops mainly when phosphorus fertilization was limiting in the soil. They concluded that Si fertilization made soil phosphorus more available to plants. Eneji et al., (2008) also found a positive correlations between $\mathrm{Si}$ and $\mathrm{P}$ uptake in grasses. The effect of $\mathrm{Si}$ on P-availability under phosphorus deficiency conditions could be due to an in planta mechanism, implying an improved utilization of phosphorus, probably through an increase in phosphorylation Cheng (1982) or a decrease in Mn concentration Ma and Takahashi (2002). In contrast, when phosphorus was supplied in excess, Si limited P uptake Ma et al. (2001).

Nitrogen, calcium and potassium: Mali and Aery (2008 a,b) observed a better absorption of $\mathrm{N}$ and $\mathrm{Ca}$ for cowpea and wheat fertilized with increasing doses of sodium metasilicate $50-800 \mathrm{mg} \mathrm{Si} \mathrm{kg}{ }^{-1}$ soil, as well as a better nodulation and apparently better N2 fixation in cowpea. Further, Ye et al. (2013) have shown that a decrease of erectness of rice leaves following excess of $\mathrm{N}$ application can be mitigated if Si is supplied to the nutrient solution. According to Mali and Aery (2008a), K uptake both in hydroponics and in soil can be improved even at low Si concentrations through the activation of $\mathrm{H}$ ATPase.

\subsection{Metal in excess}

Soil contamination with trace elements due to human activities are widespread. Metal contamination results in major physiological disturbances including reduced biomass production, photosynthesis inhibition, or disturbance of nutrient uptake. The number of studies, which tend to 
prove that Si may reduce toxicity symptoms, are steadily increasing, especially for metals of serious concern such as cadmium Sarwar et al.(2010). In soil of execs iron, in rice, it appears that Si increases the oxidizing capacity of roots, which converts ferrous iron into ferric iron, thereby preventing a large uptake of iron and limiting its toxicity Ma and Takahashi (2002). It has been suggested that $\mathrm{Si}$ could regulate Fe uptake from acidic soils through the release of $\mathrm{OH}-$ by roots when fertilized with Si Wallace (1993).

Aluminum: In most plant species, reactive oxygen species ROS production can also be induced by $\mathrm{Al}$ toxicity Kochian et al.,(2005), leading to oxidative damage of biomolecules and biological membranes Yamamoto et al., ( 2003); Singh et al., (2017). Si can regulate plant resistance and/or tolerance to metal toxicity by either external ex planta or internal in planta mechanisms (Adrees et al.,(2015); Liang et al.,(2015); Pontigo et al.,(2015); Tripathi et al.,(2015). In this regard, it has been proposed that the alleviation of Al toxicity by $\mathrm{Si}$ in plants can mainly be explained by one of the following events: i Si-induced increase in solution $\mathrm{pH}$ Li et al.,(1996); Cocker et al.,(1998a), ii formation of Al-Si complexes in the growth media Ma et al.,(2008); Cocker et al.,(1998a) or/and within the plant Corrales et al.,(1997); Cocker et al., (1998b); Britez et al., (2002); Zsoldos et al., (2003); Wang et al.,(2004); Prabagar et al.,(2011), iii exudation of organic acid anions and phenolic compounds Kidd et al.,(2001), and iv increase in the chlorophyll and carotenoid contents of leaves Singh et al.,(2017). Activation of the plant antioxidant system has also been reported in response to Si supply under Al stress Shahnaz et al.,(2011); Shen et al., (2014), (2010); Tripathi et al., (2016). Many explanations have been given to explain the effect of Si on plants in the presence of an excess of aluminum. It was assumed that $\mathrm{Si}$ and $\mathrm{Al}$ interact in the soil, creating sub-colloidal and inert aluminosilicates, thereby reducing phytotoxic aluminum concentration in the soil solution Li et al.(1999); Liang et al.(2007). Silicon may also stimulate phenolic exudates exerted by roots that would chelate and thus reduce $\mathrm{Al}$ absorption by corn roots Kidd et al. (2001).

Detoxification could be consider as another mechanism plant can be used to alleviate Altoxicity. It has been shown that aluminum can be detoxified by in planta mechanisms either by forming hydroxyl-aluminum silicates in the apoplast in roots Wang et al. (2004); Reynolds, et al. (2009) or by a sequestration in phytoliths Hodson and Sangster (1993); Hodson and Sangster (2002), which would reduce $\mathrm{Al}$ toxicity in the shoots.

The significant role of $\mathrm{Si}$ in the toxicity associated with metals, including manganese $\mathrm{Mn}$, iron $\mathrm{Fe}$, cadmium $\mathrm{Cd}$, arsenic $\mathrm{As}$, chromium $\mathrm{Cr}$, copper $\mathrm{Cu}$, lead $\mathrm{Pb}$, zinc $\mathrm{Zn}$, and $\mathrm{Al}$, has been widely reported Li et al.,(2012); Vaculík et al.,(2012); Adrees et al.,(2015); Liang et al., (2015); Pontigo et al., (2015) ; Tripathi et al.,(2015), (2016). Manganese concentration is reduced in Si-fertilized plants because Si increases Mn binding to cell walls, which limits cytoplasmic concentrations Liang et al.(2007); Rogalla and Romheld (2002).In addition, Horst et al. (1999) found that Si application lowered the apoplastic Mn concentration in cowpea leaves, suggesting that Si may modify the cation binding capacity of the cell walls. In addition, it induces a more homogenous distribution of $\mathrm{Mn}$ in leaves and cure spot necrosis Horiguchi and Morita (1987); Ma et al.(2001b); Li et al.,(2012).

Both $\mathrm{Al}$ and Si has a "soil" and a "plant" effect on the uptake of trace metals like $\mathrm{Cd}, \mathrm{Cu}$, or zinc Liang et al.(2007),(2015). Either metal concentrations in plant may decrease or increase based upon $\mathrm{Si}$ application depending on plant parts and metals. For example, rice plants taken up less $\mathrm{Cd}$ when fertilized with furnace slag due to an increase in soil $\mathrm{pH}$, thereby limiting Cd uptake, reduction of root-shoot translocation, and changes in compartmentation within the plant cell (Liang et al.(2007); Shi et al., (2005).Further, Da Cunha and do Nascimento (2009) found that fertilization of maize shoots grown on Cd- or Zn-contaminated soil with calcium silicate significantly increased shoot biomass and decrease $\mathrm{Cd}$ and $\mathrm{Zn}$ concentrations in shoots. This mainly due to changes in metal speciation in the soil rather than to $\mathrm{pH}$ increase DaCunha et al., (2008). They also observed significant structural alterations in the shoots and suggested that the deposition of silica in the endodermis and pericyclic of roots was responsible for maize tolerance to Cd and Zn stress. Liu et al. (2009), suggested that alleviation of $\mathrm{Cd}$ toxicity and accumulation in rice would be related to $\mathrm{Cd}$ sequestration in the shoot cell walls. This indicates also that Si would be able to enter leaves through the stomata. In addition, foliar application of Si decreased $\mathrm{Cd}$ concentration in rice grains and shoots while increasing their biomass. Neumann and zur Nieden (2001), reported that inside the plant zinc can precipitate with $\mathrm{Si}$ in cell walls, leading to less soluble zinc in plants. In metal-hyper accumulating plants, Zn can 
be at least temporally associated to $\mathrm{Si}$ in vesicles or in the cytoplasm before $\mathrm{Zn}$ is being stored in vacuoles, leaving $\mathrm{SiO}_{2}$ precipitates in the cytoplasm. Neumann and De Figueiredo, (2002) suggested that this mechanism might be responsible for the high $\mathrm{Zn}$ tolerance of Selene vulgaris, Thlaspi caerulescens, or Minuartia verna. Silicic acid also decreased arsenic As concentration in rice shoots grown in hydroponics, and arsenide transport in roots was shown to share the same highly efficient pathway as $\mathrm{Si}$, indicating that sufficient available $\mathrm{Si}$ in soil would be efficient at reducing $\mathrm{As}$ accumulation in rice shoots Ma et al.(2008). A whole range of mechanisms have been reviewed to explain the alleviating effect of $\mathrm{Si}$ on metal stress in planta, especially in shoots. However, the respective roles of soil and root in controlling metal uptake, and more precisely in alleviating metal stress when Si is applied to soil, have been still poorly investigated Kirkham (2006).

\section{7- Silicon fertilization:}

In some countries, silicon fertilization has become a common commercial production practice for many crops such as rice, sugar cane, and perhaps some other crops Snyder,(2007). Fertilization of silicate minerals to crops started in Japan in the early 1950s and is commonly used in many parts of the world i.e. Korea, Taiwan, Thailand, Ceylon Liang et al. (1994), (1996) and (2003) and the USA Korndörfer and Lepsch (2001). In this context, Ma and Takahashi (2002) in Japan, reported that Silicon fertilization particularly on rice growth and yield. They observed a slight increase in the panicle number, and average increase in yield by $17 \%$ as compared with the untreated one. In the case of wheat, annual application of Si-containing materials at a rate of $230 \mathrm{gkg}^{-1}$ of water-soluble Si grain were gradually increased by about $4.1-9.3 \%$ during a 4 -year field experiment Liang et al.(1994).

A large number of materials have been used as a source of Silicon for plants .Crop residues, especially of silicon accumulating plants can be used as silicon resource. Inorganic materials such as quartz, clay, mica and feldspars are rich in silicon but acts as poor silicon fertilizer because of the low solubility of the silicon .Calcium silicate obtained, as a byproduct of steel and phosphorus production is one of the most widely used silicon fertilizer. Potassium silicate is highly soluble and can be used in hydroponic culture for research related laboratory experiments. It is expensive and can not be widely used. Other sources of silicon have been used commercially are silica gel and calcium silicate hydrate Gascho, (2001). Recently, in Egypt, potassium silicate is used on large scale as foliar spray treatments to overcome a biotic stress condition, especially on vegetables and fruit crops.

In Florida, farmers are used about $900 \mathrm{~kg} \mathrm{Si} \mathrm{ha}{ }^{-1}$ year $^{-1}$ or even more for rice cultivation Korndörfer et al. (2001); Alvarez and Datnoff (2001). The economic benefits out such treatment reached to US \$74 ha ${ }^{-1}$ year $^{-1}$ (Meyer and Keeping (2001); Rodgers and Shaw (2004); Savant et al. (1997b). The most used source of silicon was wollastoniteCaSiO3, residues of blast furnaces, but also rice straw. By testing several types of Si fertilizers, including calcium silicate and rice straw, on rice crops in pots, Hossain et al. (2001), showed that rice straw offers better results in terms of Si concentration in plant. Yields are also larger when rice straw is added ground or combined with an organic matter decomposer. Experiments conducted in Japan showed that Si from rice straw used as a fertilizer is usually not fully available in the short term, but is available at more than $70 \%$ in the long term 40 years.

Inorganic silicates affect the yields faster. This led to their wide use Ma and Takahashi (2002). Foliar applications of inorganic silica have also been tested. Sarwar et al. (2010), Oliveira et al. (2012). However, Savant et al. (1997a) calculated that in 1993, the world rice production had exported 33 million tons of Sias straw that could have been reused for fertilization. Savant et al. (1997a) suggested that intensive rice cultivation with straw export might deplete the plant available silica, which could be a factor for explaining yield decline. The straw, which contains large amounts of phytoliths, should therefore be recycled because it is a source of bioavailable Si.

\section{Conclusion}

Many of the major crops are taken up Si from soil solution, but some of them are Siaccumulators. Plant $\mathrm{Si}$ also has an impact on the $\mathrm{Si}$ cycle by providing a readily efficient source of $\mathrm{Si}$ to the soil. The assumption of the depletion of plant-available silica is still pertinent, but new evidences have proven that phytoliths are a significant source of $\mathrm{Si}$ for plant. This issue is fundamental as the decrease of bioavailable Si may have significant impacts on cereal yields. In cultivated areas, the export of crops does not allow the recycling of Si by plants, and the 
biogeochemical cycle of $\mathrm{Si}$ is disturbed. Si has a positive impact on plant health and development, although, it is not considered as an essential element in plant nutrition. Seeing the manifold roles, that silicon plays in the defense system of plants against all manner of adversities. The mechanisms that regulate and allow plant Silicon to relieve all kinds of stresses are still poorly understood in details, but it is well established that ex planta and in planta processes may occur. We must admit that we are still far from formulating a 'unified field theory' about the important role of silicon in agriculture.

\section{References}

Adrees, M., S. Ali, M.Rizwan, M.Zia-ur-Rehman, M. Ibrahim, F. Abbas, et al., 2015. Mechanisms of silicon-mediated alleviation of heavy metal toxicity in plants: a review. Ecotoxicol. Environ. Saf. 119, 186-197.

Ahmed, M., A. Kamran, M. Asif, U.Qadeer, Z. I.Ahmed, and A. Goyal, 2013. Silicon priming: a potential source to impart abiotic stress tolerance in wheat: a review. Aust. J. Crop Sci. 7, 484491.

Aimé, S., C. Alabouvette, C. Steinberg, and C. Olivain, 2013. The endophytic strain Fusarium oxysporum Fo47: a good candidate for priming the defense responses in tomato roots. Mol. Plant Microbe Interact. 26, 918-926.

Alexandre, A., J.D. Meunier, F. Colin and J.M. Koud, 1997. Plant impact on the biogeochemical cycle of silicon and related weathering processes. Geochimica et Cosmochimica Acta 613:677682

Alvarez, J. and L.E. Datnoff, 2001.The economic potential of silicon for integrated management and sustainable rice productions. Crop Prot., 20:43-48

Barbosa, Filho, M.P., G.H. Snyder, N.K. Fageria, L.E. Datnoff, and O.F. Silva, 2001. Silicato de cálcio como fonte de silício para o arroz de sequeiro. Revista Brasileira de Ciência do Solo.;25:325-330 Tubana BS, Heckman JR. Silicon in Soils and Plants. Vol. 133. Springer; 2015. pp. 7-51.

Bartoli, F., 1983. The biogeochemical cycle of silicon in two temperate foresty ecosystems. In: Hallberg R ed Environmental biogeochemistry. Ecol Bull Stockholm, vol 35, pp 469-476.

Bélanger, R., N.Benhamou, and J.Menzies, 2003. Cytological evidence of an active role of silicon in wheat resistance to powdery mildew Blumeria graminis f. sp. tritici. Phytopathology 93, 402412.

Berner, E.K. and R.A. Berner, 1996. Global environment: water, air, and geochemical cycles. Prentice Hall, New Jersey.

Berthelsen, S., and G.H. Korndörfer, 2012. Methods for Silicon Analysis in Soil, Plant and Fertilizers. 2003. Available from [Accessed: 03-07-].

Blecker, S.W., R.L. McCulley, O.A. Chadwick and E.F. Kelly, 2006. Biological cycling of silica across a grassland bioclimosequence.Global Biogeochemical Cycles, 20:1-11

Bogdan, K., and M.K. Schenk, 2008. Arsenic in rice Oryza sativa L. related to dynamics of arsenic and silicic acid in paddy soils. Environ Sci. Technol, 42:7885-7890.

Bouzoubaa, Z., 1991. Etude des rôles de la silice dans les mécanismes de tolérance à la sécheresse chez quelques espèces de grande culture. $\mathrm{PhD}$ thesis, Montpellier II University.

Britez, R. M., T.Watanabe, S.Jansen, C. B.Reissmann, and M.Osaki, 2002. The relationship between aluminium and silicon accumulation in leaves of Faramea marginata Rubiaceae. New Phytol. 156, 437-444.

Brunings, A. M., Datnoff, L. E., Ma, J. F., Mitani, N., Nagamura, Y., Rathinasabapathi, B., et al. 2009. Differential gene expression of rice in response to silicon and rice blast fungus Magnaporthe oryzae. Ann. Appl. Biol. 155, 161-170. doi: 10.1111/j.1744-7348.2009.00347.x

Cai, A.Y., Z.Z.Xue, J.G.Peng, H.D.Lu, and Y.J. Lin, 1997. Studies of available silica content in the soils of Fujian province and the prerequisite for its variation. J. Fujian Acad. Agric. Sci., 124:4751 In Chinese with English abstract.

Cai, K., D.Gao, S.Luo, R.Zeng, J.Yang, and X. Zhu, 2008. Physiological and cytological mechanisms of silicon-induced resistance in rice against blast disease. Physiol. Plant. 134, 324-333. 
Cai, K., D.Gao, S.Luo, R.Zeng, J.Yang, and X. Zhu, 2008. Physiological and cytological mechanisms of silicon-induced resistance in rice against blast disease. Physiol. Plant. 134, 324-333.

Carver, T.L.W., M.P.Robbins, B.J.Thomas, K.Troth, N.Raistrick, and R.J. Zeyen, 1998. Silicon deprivation enhances localized autofluorescent responses and phenylalanine ammonia-lyase activity in oat attacked by Blumeria graminis. Physiol. Mol. Plant Pathol., 52, 245-257.

Casey, W.H., S.D. Kinrade, C.T.G. Knight, D.W. Rains and E. Epstein, 2004. Aqueous silicate complexes in wheat, Triticum aestivum L. Plant Cell and Environment. 27:51-54.

Chen, Y. Y., Lin, Y. M., Chao, T. C., Wang, J. F., Liu, A. C., Ho, F. I., et al. 2009. Virus-induced gene silencing reveals the involvement of ethylene-, salicylic acid- and mitogen-activated protein kinase-related defense pathways in the resistance of tomato to bacterial wilt. Physiol. Plant. 136, 324-335. doi: 10.1111/j.1399-3054.2009.01226.x

Cheng, B.T., 1982. Some significant functions of silicon to higherplants. Journal of Plant Nutrition 5:1345-1353 Cheong YWY, Chan PY (1973) Incorporation of P32 in phosphate esters of the sugar caneplant and the effect of $\mathrm{Si}$ and $\mathrm{Al}$ on the distribution of these esters. Plant and Soil, $38: 113-123$.

Chérif, M., A.Asselin, and R.Bélanger, 1994. Defense responses induced by soluble silicon in cucumber roots infected by Pythium spp. Phytopathology 84, 236-242.

Cherif, M., J.G.Menzies, N. Benhamou, and R.R. Belanger, 1992. Studies of silicon distribution in wounded and Pythium ultimum infected cucumber plants. Physiological and Molecular Plant Pathology, 41, 371-385.

Clarke, J., 2003. The occurrence and significance of biogenic opal in the regolith. Earth-Science Reviews, 60:175-194.

Cocker, K. M., D. E.Evans, and M. J. Hodson, 1998a. The amelioration of aluminium toxicity by silicon in higher plants: solution chemistry or an in plants mechanism? Physiol. Plant. 104, 608614.

Cocker, K. M., D. E.Evans, and M. J. Hodson, 1998b. The amelioration of aluminium toxicity by silicon in wheat Triticum aestivum L.: malate exudation as evidence for an in planta mechanism. Planta 204, 318-323.

Conley, D.J. (2002).Terrestrial ecosystems and the global biogeochemical silica cycle. Global Biogeochem Cycles., 16:1121.

Cornelis, J.T., B.Delvauz, R.B.Georg, Y.Lucas, J.Ranger, and S.Opfergelt, 2011. Tracing the origin of dissolved silicon transferred from various soil-plant systems towards rivers: A review. Biogeosciences.;8:89-112.

Cornelis, J.T., J. Ranger, A. Iserentant and B, Delvaux., 2010. Tree species impact the terrestrial cycle of silicon through various uptakes. Biogeochemistry, 97:231-245.

Corrales I., C.Poschenrieder, and J.Barceló, 1997. Influence of silicon pretreatment on aluminium toxicity in maize roots. Plant Soil, 190 203-209. 10.1023.

Costa, R. R., J. C.Moraes, and R. R. DaCosta, 2011. Feeding behaviour of the greenbug Schizaphis graminum on wheat plants treated with imidacloprid and/or silicon. J. Appl. Entomol. 135, 115120.

Côté-Beaulieu, C., F. Chain, J.G. Menzies, S.D. Kinrade and R.R. Bélanger, 2009. Absorption of aqueous inorganic and organic silicon compounds by wheat and their effect on growth and powdery mildew control. Environ Exp. Bot. 65:155-161.

Currie, H.A., and C.C. Perry, 2007. Silica in plants: biological, biochemical and chemical studies. Annals of Botany, 100, 1383-1389.

da Cunha, K.P.V. and C.W.A. do Nascimento, 2009. Silicon effects on metal tolerance and structural changes in maize Zea mays L. grownon a cadmium and zinc enriched soil. Water Air and Soil Pollution, 197:323-330.

da Cunha, K.P.V., C.W.A. do Nascimento and A.J. da Silva, 2008. Silicon alleviates the toxicity of cadmium and zinc for maize Zea mays L. grown on a contaminated soil. Journal of Plant Nutrition and Soil Science, 171:849-853.

Dai, G.L., H.S.Duanmu, Z.Wang, Y.B.Zhao, G.Zhu, and J.Zhou, 2004. Study on characteristics of available silicon content in Shaanxi province. J. Soil Water Conserv., 18:51-3 In Chinese with English abstract. 
Datnoff, L.E., and F.A. Rodrigues, 2015. History of silicon and plant disease. In: Rodrigues FA, Datnoff LE, editors. Silicon and Plant Diseases. Springer; pp. 1-6. DOI: 10.1007/978-3-31922930-0.

Datnoff, L.E., G.H. Snyder and G.H. Korndorfer, 2001. Silicon in agriculture. Studies in Plant Science 8. Elsevier, Amsterdam.

Deren, C.W., 2001. Plant genotype, silicon concentration, and siliconrelated responses. In: Datnoff LE, Snyder GH, Korndorfer GH eds Silicon in agriculture. Studies in plant science, 8. Elsevier, Amsterdam, pp 149-158.

Derry, L.A., A.C. Kurtz, K. Ziegler and O.A. Chadwick, 2005. Biological control of terrestrial silica cycling and export fluxes to watersheds. Nature, 433:728-731.

Deshmukh, R., and R.Bélanger, 2015. Molecular evolution of aquaporins and silicon influx in plants. Funct. Ecol. doi: 10.1111/1365-2435.12570.

Dietrich, D., S. Hinke, W. Baumann, R. Fehlhaber, E. Baucher, G. Ruhle, O. Wienhaus and G. Marx, (2003). Silica accumulation in Triticum aestivum L. and Dactylis glomerata L. Anal Bioanal Chem. 376:399-404.

Ding, T.P., J.X. Zhou, D.F. Wan, Z.Y. Chen, C.Y. Wang and F. Zhang, 2008. Silicon isotope fractionation in bamboo and its significance to the biogeochemical cycle of silicon. Geochimica et Cosmochimica Acta. 72:1381-1395.

Eneji, A.E., S. Inanaga, S. Muranaka, J. Li, T. Hattori, P. An, W. Tsuji, 2008. Growth and nutrient use in four grasses under drought stress as mediated by silicon fertilisers. Journal of Plant Nutrition, 31:355-365.

Epstein, E., 1999. Silicon. Annual Review of Plant Physiology and Plant Molecular Biology, 50, 64166

Epstein, E. and A.J. Bloom, 2003. Mineral Nutrition of Plants: Principles and Perspectives, 2nd Ed., John Wiley \& Sons, New York.

Epstein, E., 1994. The anomaly of Si in plant biology. Proc. Natl. Acad. Sci. USA, 91, 11-17.

FAOSTAT.,( 2014). Top production-World total in 2012. Retrieved in Dec. 22,2014. Available online at http://faostat.fao.org/site/339/default.aspx.

Fauteux, F., F.Chain, F.Belzile, J. G.Menzies, and R. R. Belanger, 2006. The protective role of silicon in the Arabidopsis-powdery mildew pathosystem. Proc. Natl. Acad. Sci. U.S.A. 103, 1755417559.

Fauteux, F., W. Remus-Borel, J.G. Menzies and R.R. Bélanger, 2005. Silicon and plant disease resistance against pathogenic fungi. FEMS Microbiol Lett. 249:1-6.

Fawe, A., M.Abou-Zaid, J. G.Menzies, and R. R. Bélanger, 1998. Silicon-mediated accumulation of flavonoid phytoalexins in cucumber. Phytopathology 88, 396-401.

for brown patch and dollar spot suppression on turfgrasses. Crop Sci. 46, 1635-1643. doi: 10.2135/cropsci2005.04-0002

Fu, F.F., T.Akagi and S.Yabuki,2002. Origin of silica particles found in the cortex of Matteuccia roots. Soil Science Society of America Journal 66:1265-1271

Gascho, G.J. (2001) Silicon sources for agriculture. In: Datnoff LE, Snyder GH, Korndorfer GH eds Silicon in agriculture. Studies in plant science, 8. Elsevier, Amsterdam, pp 197-207

Gérard, F., K.U.Mayer, M.J.Hodson, and J. Ranger, 2008. Modelling the biogeochemical cycle of silicon in soils: application to a temperate forest ecosystem. Geochim Cosmochim. Acta.; 72:741-58.

Ghanmi, D., D.J.McNally, N.Benhamou, J.G.Menzies and R.R. Bélanger, 2004 .Powdery mildew of Arabidopsis thaliana: a pathosystem for exploring the role of silicon in plant-microbe interactions. Physiological and Molecular Plant Pathology64:189-199

Ghareeb, H., Z.Bozsó, P. G.Ott, C.Repenning, F.Stahl, and K.Wydra, 2011. Transcriptome of siliconinduced resistance against Ralstonia solanacearum in the silicon non-accumulator tomato implicates priming effect. Physiol. Mol. Plant Pathol. 75, 83-89.

Gomes, F. B., J. C. D.Moraes, C. D. D.Santos, and M. M. Goussain, 2005. Resistance induction in wheat plants by silicon and aphids. Sci. Agric. 62, 547-551.

Hao, Z., L.Fayolle, D.van Tuinen, O.Chatagnier, X. Li, S.Gianinazzi, et al., 2012. Local and systemic mycorrhiza-induced protection against the ectoparasitic nematode Xiphinema index involves priming of defence gene responses in grapevine. J. Exp. Bot. 63, 3657-3672. 
Hartley, S. E., R. N.Fitt, E. L.McLarnon, and R. N. Wade, 2015. Defending the leaf surface: intra- and inter-specific differences in silicon deposition in grasses in response to damage and silicon supply. Front. Plant Sci. 6:35.

Hartmann, T., 2008 . The lost origin of chemical ecology in the late 19th century. Proceedings of the National Academy of Sciences of the United States of America, 105, 4541-4546.

Hattori, T., H. Inanaga, H. Araki, P.An, S.Morita, M. Luxova, and A. Lux, 2005. Application of silicon enhanced drought tolerance in Sorghum bicolor. Physiol Plant, 123:459-466.

Hattori, T., S.Inanaga, E.Tanimoto, A. Lux, M.Luxova and Y.Sugimoto,2003. Silicon-induced changes in viscoelastic properties ofsorghum root cell walls. Plant and Cell Physiology, 44:743749.

Haynes, R.J., 2014 . A contemporary overview of silicon availability in agricultural soils. Journal of Plant Nutrition and Soil Science.; 177:831-844.

He, L.Y., and X.L. Li, 1995. Content and distribution of available silicon in paddy soils of Hubei province. J Huazhong Agric Univ.; 14:363-8 In Chinese with English abstract.

Henriet, C., X. Draye, I.Oppitz, R.Swennen, and B.Delvaux, 2006. Effects, distribution and uptake of silicon in banana Musa spp. under controlled conditions. Plant and Soil, 287:359-374.

Hodson M. J., P. J. White, A. Mead, and M. R. Broadley, 2005. Phylogenetic variation in the silicon composition of plants. Ann. Bot. 96:1027-1046.

Hodson, M. J., and A. G. Sangster, 1993. The interaction between silicon and aluminium in Sorghum bicolor L. Moench: growth analysis and X-ray microanalysis. Ann. Bot. 72, 389-400.

Hodson, M.J, and A.G. Sangster,1988. Observations on the distribution of mineral elements in the leaf of wheat Triticum aestivum L., with particular reference to silicon. Ann. Bot., 62:463-471.

Hodson, M.J. and A.G. Sangster,2002. X-ray microanalytical studies of mineral localization in the needles of white pine Pinus strobus L.. Ann Bot 89:367-374

Hodson, M.J., P.J.White, A. Mead, and M.R. Broadley,2005. Phylogenetic variation in the silicon composition of plants. Ann. Bot. 96:1027- 1046.

Hogenhout, S. A., and J. I. Bos, 2011. Effector proteins that modulate plant-insect interactions. Curr. Opin. Plant Biol. 14, 422-428.

Horiguchi, T., and S.Morita, 1987. Mechanism of manganese toxicity and tolerance of plants. VI. Effect of silicon on alleviation of manganese toxicity of barley. Journal of Plant Nutrition, 10:2299-2310.

Horst, W.J., M.Fecht, A.Naumann, A.H. Wissemeier, and P.Maier, 1999 .Physiology of manganese toxicity and tolerance in Vigna unguiculata L. Walp. Journal of Plant Nutrition and Soil Science, 162:263-274.

Hossain, K.A., T.Horiuchi, and S. Miyagawa,2001. Effects of silicate materials on growth and grain yield of rice plants grown in clay loam and sandy loam soils. Journal of Plant Nutrition, 24:1-13.

Husnain, T.Wakatsuki, D.Setyorini, S.K.Hermansah, and T.Masunaga, 2008.Silica availability in soils and river water in two watersheds on Java Island, Indonesia. Soil Sci. Plant Nutr.; 54:91627.

Inanaga. S., A.Okasaka, and S .Tanaka,1995. Does silicon exist inassociation with organiccompounds in rice plant? Soil Science and Plant Nutrition, 41:111-117.

Jung, H. W., T. J. Tschaplinski, L.Wang, J.Glazebrook, and J. T. Greenberg, 2009. Priming in systemic plant immunity. Science 324, 89-91.

Kauss, H., K.Seehaus, R.Franke, S.Gilbert, R.A.Dietrich, and N. Kroger, 2003. Silica deposition by a strongly cationic proline-rich protein from systemically resistant cucumber plants. Plant 1., 33, $87-95$.

Kawaguchi, K., and K.Kyuma, 1977. Paddy soils in tropical Asia, their material nature and fertility. Honolulu: University Press of Hawaii.

Keeping, M. G., O. L. Kvedaras, and A. G. Bruton.2009. Epidermal silicon in sugarcane: Cultivar differences and role in resistance to sugarcane borer Eldana saccharina. Environ. Exp. Bot. 66:54-60.

Kidd, P. S., M.Llugany, C.Poschenrider, B.Gunse, and J.Barcelo, 2001. The role of roots exudates in aluminium resistence and silicon- induced amelioration of aluminium toxicity in three varieties of maize Zea mays L. J. Exp. Bot. 52, 1339-1352. 
Kirkham, M.B.,2006. Cadmium in plants on polluted soils: effects of soil factors, hyperaccumulation, and amendments. Geoderma, 137:19-32.

Kochian, L. V., M. A.Pineros, and O. A. Hoekenga, 2005. The physiology, genetics and molecular biology of plant aluminum resistance and toxicity. Plant Soil 274, 175-195.

Korndörfer G.H., H.S.Pereira, and M.S. Camargo, 2002. Papel do silício na produção de cana de açúcar. STAB.;21:6-9.

Korndörfer, G.H. and I. Lepsch, 2001. Effect of silicon on plant growth and crop yield. In: Datnoff LE, Snyder GH, Korndorfer GH eds Silicon in agriculture. Studies in plant science, 8. Elsevier, Amsterdam, pp 133-147.

Korndörfer, G.H., G.H.Snyder, M.Ulloa, G.Powell and L.E.Datnoff, 2001.Calibration of soil and plant silicon analysis for rice production Journal of Plant Nutrition, 24:1071-1084.

Kvedaras, O. L., M. G.Keeping, R.Goebel, and M.Byrne, 2010. Silicon enhances natural enemy attraction and biological control through induced plant defences. Bull. Entomol. Res. 100, 367371.

Leng, M.J., G.E.A.Swann, M.J.Hodson, J.J.Tyler, S.V.Patwardhan, and H.J. Sloane ., 2009. The potential use of silicon isotope composition of biogenic silica as a proxy for environmental changes. Silicon, 1:65-77.

Li, P., A.Song, Z. Li, F.Fan, and Y.Liang, 2012. Silicon ameliorates manganese toxicity by regulating manganese transport and antioxidant reactions in rice Oryza sativa L.. Plant Soil, 354, 404-419.

Li, Z.Z., Q.X.Tao, G.R.Liu, H.Z.Zhang, and Y.R. Liu, 1999. Investigation of available silicon content in cultivated soil in Jiangxi province. Acta Agric Jiangxi. 9, 11:1-9 In Chinese with English abstract.

Liang, Y., and W.C. Sun, 2007. Mechanisms of silicon-mediated alleviation of abiotic stresses in higher plants: A review. Environmental Pollution.147:422-428.

Liang, Y., M.Nikolic, R.Bélanger, H.Gong, and A.Song, 2015. Silicon in Agriculture. Dordrecht: Springer, 10.1007/978-94-017-9978-2.

Liang, Y.C., H.X.Hua, Y.G.Zhu, J.Zhang, C.M.Cheng, and V.Römheld, 2006. Importance of plant species and external silicon concentration to active silicon uptake and transport. New Phytol.; $172: 63-72$.

Liang, Y.C., J.Si, and V.Römheld, 2005. Silicon uptake and transport is an active process in Cucumis sativus . New Phytol.; 167:797-804.

Liang, Y.C., Q.Chen, Q.Liu, W.H.Zhang and R.X. Ding 2003. Exogenous silicon Si increases antioxidant enzyme activity and reduces lipid peroxidation in roots of salt-stressed barley Hordeum vulgare L.. Journal of Plant Physiology, 160:1157-1164.

Liang, Y.C., Q.R.Shen, Z.G.Shen, and T.S.Ma, 1996.Effects of silicon on salinity tolerance of two barley cultivars. Journal of PlantNutrition, 19:173-183.

Liang, Y.C., T.S.Ma, F.J.Li, and Y.J.Feng, 1994. Silicon availability and response of rice and wheat to silicon in calcareous soils. Communications in Soil Science and Plant Analysis, 25:22852297.

Liang, Y.C., W.C.Sun, Y.G.Zhu, and P.Christie, 2007. Mechanisms of silicon-mediated alleviation of abiotic stresses in higher plants: a review. Environ Pollut., 147:422-428.

Liu, C., F.Li, C.Luo, X.Liu, S.Wang, T.Liu and X.Li, 2009. Foliar application of two silica sols reduced cadmium accumulation in rice grains. J. Hazard Mater, 161:1466-1472.

Lucas, Y., F.J.Luizão, A.Chauvel, J.Rouiller, and D.Nahon, 1993. The relation between biological activity of the rain forest and mineral composition of soils Science, 260:521-523.

Lux, A., M.Luxová, J.Abe, E.Tanimoto, T.Hattori, and S.Inanaga, 2003. The dynamics of silicon deposition in the sorghum root endodermis. New Phytologist, 158:437-441.

Ma, J.F.( 2004). Role of silicon in enhancing the resistance of plants to biotic and abiotic stresses. Soil Science and Plant Nutrition 50: 11-18.

Ma, J.F., and E.Takahashi, 2002. Soil, fertiliser and plant silicon research inJapan. Elsevier, Amsterdam.

Ma, J.F., and N.Yamaji, 2006 .Silicon uptake and accumulation in higher plants. Trends in Plant Science, 11:392-397. 22. 
Ma, J.F., S. Goto, K. Tamai and M. Ichii, 2001a. Role of root hairs and lateral roots in silicon uptake by rice. Plant Physiol., 1 27:1773-80.

Ma, J.F., N.Mitani, S.Nagao, S.Konishi, K.Tamai, T.Iwashita, and M.Yano, 2004. Characterization of the silicon uptake system and molecular mapping of the silicon transporter gene in rice. Plant Physiology, 136:3284-3289.

Ma, J.F., N.Yamaji, N.Mitani, X.X.Xu, Y.H.Su, S.P.McGrath and F.J.Zhao, 2008. Transporters of arsenite in rice and their role in arsenic accumulation in rice grain. PNAS.105:9931-9935.

Ma, J.F., Y. Miyake, and E.Takahashi, 2001b. Silicon as a beneficial element for crop plants. In: Datnoff LE, Snyder GH, Korndorfer GH eds Silicon in agriculture. Studies in plant science, Elsevier, Amsterdam. The Netherlands, Volume 8, pp. 17-39.

Makabe, S., K. Kakuda, Y.Sasaki, T.Ando, H.Fujii, and H.Ando,2009. Relationship between mineral composition or soil texture and available silicon in alluvial paddy soils on the Shounai Plain, Japan. Soil Science and Plant Nutrition, 55:300-308.

Mali, M., and N.C.Aery, 2008b. Silicon effects on nodule growth, dry matter production, and mineral nutrition of cowpea Vigna unguiculata. Journal of Plant Nutrition and Soil Science, 171:835840.

Mali, M., and N.C.Aery,2008a .Influence of silicon on growth, relative water contents and uptake of silicon, calcium and potassium in wheat grown in nutrient solution. Journal of Plant Nutrition, 31:1867-1876.

Manivannan, A., P.Soundararajan, S.Muneer, C.Ho Ko, and B.R. Jeong, 2016. Silicon mitigates salinity stress by regulating the physiology, antioxidant enzyme activities, and protein expression in Capsicum annuum "Bugwang". BioMed Research International.;1-15.

Massey, F. P., A. R.Ennos, and S. E. Hartley, 2007. Herbivore specific induction of silica-based plant defences. Oecologia, 152, 677-683.

Matichenkov, V.V, and E.A. Bocharnikova,2001. The relationship between silicon and soil physical and chemical properties. In: Datnoff LE,Snyder GH, Korndorfer GH eds Silicon in agriculture. Studies in plant science, 8. Elsevier, Amsterdam, pp 209-219.

McNaughton, S. J., and J. L. Tarrants, 1983. Grass leaf silicification: natural selection for an inducible defense against herbivores. Proc. Natl. Acad. Sci. U.S.A. 80, 790-791.

Meena, V.D., M.L.Dotaniya, and V.Coumar, (2014). A case for silicon fertilization to improve crop yields in tropical soils. Proceedings of the National Academy of Sciences.;84:505-518.

Meyer, J.H., and M.G. Keeping. (2001). Past, present and future research of the role of silicon for sugarcane in southern Africa. In: Datnoff LE, Snyder GH, Korndörfer GH, editors. Silicon in Agriculture. Amsterdam: Elsevier Science;. pp. 257-276.

Mitani, N., and J.F.Ma, 2005. Uptake system of silicon in different plant species. J. Exp. Bot., 56:1255-1261.

Mitani, N., N.Yamaji, and J.F.Ma, 2009. Identification of maize silicon influx transporters. Plant and Cell Physiology, 50:5-12.

Motomura, K., T.Fuji, and M.Suzuki, 2004. Silica deposition in relation to ageing of leaf tissues in Sasa veitchii Carrière Rehder Poaceae: Bambusoideae. Ann. Bot., 93:235-248.

Neumann, D., and C.De Figueiredo, 2002. A novel mechanism of silicon uptake. Protoplasma, 220:59-67.

Neumann, D., and U. zur Nieden,2001. Silicon and heavy metal tolerance of higher plants. Photochemistry, 56:685-692.

Nikolic, M., N. Nikolic, Y.C. Liang, E.A. Kirkby, V. Römheld, 2007. Germanium-68 as an adequate tracer for Si transport in plants. Characterization of Si uptake in different crop species. Plant Physiol., 143, 495-503.

Oliveira, J.C., G.M.R.Albuquerque, R.L.R.Mariano, D.M.F.Gondim, T.A.Oliveira, and E.B. Souza, 2012. Reduction of the severity of angular leaf spot of cotton mediated by silicon. Journal of Plant Pathology, 942: 297-304.

Pereira, H.S., N.C.Barbosa, M.A.C.Carneiro, and G.H. Korndörfer, 2007. Avaliação de fontes e de extratores de silício no solo. Pesquisa Agropecuária Brasileira.;42:239-247.

Perry, C.C., and T.Keeling-Tucker,1998. Aspects of the bioinorganic chemistry of silicon in conjunction with the biometals calcium, iron and aluminium. J. Inorg. Biochem., 69:181-191. 
Pontigo S., A.Ribera, L.Gianfreda, M. L.Mora, M.Nikolic, and P. Cartes, 2015. Silicon in vascular plants: uptake, transport and its influence on mineral stress under acidic conditions. Planta, 242 23-37.

Ponzi, R., and P.Pizzolongo,2003. Morphology and distribution of epidermal phytoliths in Triticum aestivum L. Plant Biosystems, 137:3-10.

Prabagar, S., M. J.Hodson, and D. E. Evans, 2011. Silicon amelioration of aluminium toxicity and cell death in suspension cultures of Norway spruce Picea abies L. Karst.. Environ. Exp. Bot. 70, 266276.

Prychid, C.J., P.J.Rudall, and M.Gregory,2003. Systematics and biology of silica bodies in monocotyledons. Bot. Rev., 69:377-440.

Prychid, C.J., P.J.Rudall, and M.Gregory, 2004. Systematics and biology of silica bodies in monocotyledons. The Botanical Review 69: 377-440.

Rafi, M.M., E.Epstein, and R.H. Falk (1997). Silicon deprivation causes physical abnormalities in wheat Triticum aestivum L.. Journal of Plant Physiology, 151, 497-501.

Rahman, A., C.Wallis, and W.Uddin, 2015. Silicon induced systemic defense responses in perennial ryegrass against infection by Magnaporthe oryzae. Phytopathology 105, 748-757.

Rains, D.W., E.Epstein, R.J.Zasoski, and M. Aslam, 2006. Active silicon uptake by wheat plants. Journal of Plant Physiology, 166:1413-1422.

Raven .J.A., 1983. The transport and function of silicon in plants. Biological Reviews, 58(2): 179207.

Raven, J.A., 2001. Si transport at the cell and tissue level. In Si in Agriculture, Studies in Plant Science, Datnoff, L.E., Snyder, G.H., Korndörfer, G.H., Eds., Elsevier: Amsterdam, The Netherlands, Volume 8, pp. 41- 55.

Raven, J.A., Cycling silicon-the role of accumulation in plants. New Phytol. (2003),158:419-21.

Rémus-Borel, W., J. G.Menzies, and R. R. Bélanger, 2005. Silicon induces antifungal compounds in powdery mildew-infected wheat. Physiol. Mol. Plant Pathol. 66, 108-115 Review of the Cambridge Philosophical Society.58:179-207.

Richmond, K. E., and M. Sussman, 2003. Got silicon. The non-essential beneficial plant nutrient. Curr. Opin. Plant Biol., 6:268-272.

Rodgers-Gray, B.S., and M.W.Shaw, 2004. Effects of straw and silicon soil amendments on some foliar and stem-base diseases in pot-grown winter wheat. Plant Pathology, 53:733-740.

Rodrigues, F. A., D. J.McNally, L. E. Datnoff, J. B.Jones, C. Labbe, N.Benhamou, et al. 2004. Silicon enhances the accumulation of diterpenoid phytoalexins in rice: a potential mechanism for blast resistance. Phytopathology 94, 177-183.

Rodrigues, F.A., L.A.Oliveira, A.P.Korndorfer, and G.H. Korndorfer Silício, 2011. Um elemento benéfico e importante para as plantas. Informações Agronômicas.;134:14-20.

Rogalla, H., and V.Romheld, 2002. Role of leaf apoplast in siliconmediated manganese tolerance of Cucumis sativus L. Plant Cell and Environment., 25:549-555.

Sangster, A.G., 1978. Silicon in roots of higher plants. Am. J. Bot., 65:929-935.

Sangster, A.G., M.J.Hodson, and H.J. Tubb, 2001. Silicon deposition in higher plants. In: Datnoff LE, Snyder GH, Korndorfer GH eds Silicon in agriculture. Studies in plant science, 8. Elsevier, Amsterdam, pp 85-113.

Sarwar, N., Saifullah, S.S. Malhi, M.H. Zia, A.Naeem, S.Bibi, and G.Farid, 2010. Role of mineral nutrition in minimizing cadmium accumulation by plants. J. Sci. Food Agric., 90:925-937.

Savant, N.K., G.H.Snyder, and L.E. Datnoff, 1997b. Silicon management and sustainable rice production. Adv. Agron. 58:151-199.

Savant, N.K., L.E.Datnoff, and G.H. Snyder, 1997a. Depletion of plant-available silicon in soils: a possible cause of declining rice yields. Communications in Soil Science and Plant Analysis, 28:1245-1252.

Shahnaz, G., E.Shekoofeh, D.Kourosh, and B.Moohamadbagher, 2011. Interactive effects of silicon and aluminum on the malondialdehyde MDA, proline, protein and phenolic compounds in Borago officinalis L. J. Med. Plants Res. 5, 5818-5827.

Shen, X., X.Xiao, Z.Dong, and Y.Chen, 2014. Silicon effects on antioxidative enzymes and lipid peroxidation in leaves and roots of peanut under aluminum stress. Acta Physiol. Plant. 36, 30633069. 
Shen, X., Y.Zhou, L.Duan, A.E.Eneji, and J.Li, 2010. Silicon effects on photosynthesis and antioxidant parameters of soybean seedlings under drought and ultraviolet-B radiation. Journal of Plant Physiology, 167:1248-1252.

Shi, X.H., C.C.Zhang, H.Wang, and F.S. Zhang, 2005. Effect of Si on the distribution of Cd in rice seedlings. Plant and Soil, 272:53-60 Sommer M, Kaczorek D, Kuzyakov Y, Breuer J 2006 Silicon pools and fluxes in soils and landscapes - a review. Journal of Plant Nutrition and Soil Science, 169:310-329.

Shi, X.H., C.C.Zhang, H.Wang, and F.S. Zhang, 2005. Effect of Si on the distribution of Cd in rice seedlings. Plant and Soil, 272:53-60 Sommer M, Kaczorek D, Kuzyakov Y, Breuer J 2006 Silicon pools and fluxes in soils and landscapes - a review. Journal of Plant Nutrition and Soil Science, 169:310-329.

Singh S., D. K.Tripathi, S.Singh, S.Sharma, N. K.Dubey, D. K.Chauhan, et al. 2017. Toxicity of aluminium on various levels of plant cells and organism: a review. Environ. Exp. Bot. 137177 193.

Slaughter, A., X.Daniel, V.Flors, E.Luna, B.Hohn, and B.Mauch-Mani, 2012. Descendants of primed Arabidopsis plants exhibit resistance to biotic stress. Plant Physiol. 158, 835-843.

Smith, M. T., O. L.Kvedaras, and M. G. Keeping, 2007. A novel method to determine larval mandibular wear of the African stalk borer, Eldana saccharina walker Lepidoptera: Pyralidae. Afr. Entomol. 15, 204-208.

Snyder, G. H., V. V. Martichenkov, and L. E. Datnoff, 2007. Silicone. In: Handbook of Plant Nutrition. Barker A. V., and D. J. Pilbean eds.. CRC Taylor and Francis, New York, USA, pp. 551-568.

Sommer M., D.Kaczorek, Y.Kuzyakov, and J.Breuer, 2006. Silicon pools and fluxes in soils and landscapes - a review. J. Plant Nutr. Soil Sci. 169, 310-329.

Stanley, J. N., H. A.Baqir, and T. I. McLaren, 2014. Effect on larval growth of adding finely ground silicon-bearing minerals wollastonite or olivine to artificial diets for Helicoverpa spp. Lepidoptera: Noctuidae. Austral Entomol. 53, 436-443.

Struyf, E., A.Smis, S.Van Damme, J.Garnier, G.Govers, B.Van Wesemael, D.J.Conley, O.Batelaan, E. Frot, W.Clymans, F.Vandevenne, C.Lancelot, P.Goos, and P.Meire, 2010b .Historical land use change has lowered terrestrial silica mobilization. Nature Commun. 2010b.

Struyf, E., A. Smis, S. Van Damme, P. Meire and D.J. Conley, 2010a. The global biogeochemical silicon cycle. Silicon;1:207-13.

Taiz, L., and E. Zeiger, Fisiologia, 2013. Vegetal. Techbooks. 5th ed. Dados eletrônicos. Porto Alegre: Artmed;. p. 918.

Tamai, K., and J.F. Ma, 2003. Characterization of silicon uptake by rice roots. New Phytol.;158:4316.

Ton, J., C. M.Pieterse, and L.Van Loon, 2006. "The relationship between basal and induced resistance in Arabidopsis," in Multigenic and Induced Systemic Resistance in Plants, eds S. Tuzun and E. Bent New York, NY: Springer, 197-224.

Trembath-Reichert, E., J.P.Wilson, S.E.McGlynn, and W.W. Fischer, 2015. Four hundred million years of silica biomineralization in land plants. Proceedings of the National Academy of Sciences, USA 112: 5449-5454.

Tripathi, D. K., G.Bashri, S.Singh, S.Singh, P.Ahmad, S. M.Prassad, et al. 2016. "Efficacy of silicon against aluminum toxicity in plants: an overview," in Silicon in Plants: Advances and Future Prospects, eds D. K. Tripathi, V. P. Singh, P. Ahmad, D. K. Chauhan, and S. M. Prasad Boca Raton, FL: CRC Press, 355-366.

Tripathi, D. K., V. P.Singh, S. M.Prasad, D. K.Chauhan, N. K.Dubey, and A. K. Rai, 2015. Siliconmediated alleviation of $\mathrm{Cr}$ VI toxicity in wheat seedlings as evidenced by chlorophyll florescence, laser induced breakdown spectroscopy and anatomical changes. Ecotoxicol. Environ. Saf. $113,133-144$.

Tubana, B.S., T.Babu, and L.E. Datnoff, 2016. A review of silicon in soils and plants and its role in US agriculture: History and future perspectives. Soil Science.,181:393-411.

Vaculík, M., T. Landberg, M. Greger, M. Luxová, M. Stoláriková, and A. Lux, 2012. Silicon modifies root anatomy, and uptake and subcellular distribution of cadmium in young maize plants. Ann. Bot. 110, 433-443. 
Van Bockhaven, J., D. De Vleesschauwer, and M.Hofte, 2013. Towards establishing broad-spectrum disease resistance in plants: silicon leads the way. J. Exp. Bot. 64, 1281-1293. doi: 10.1093/jxb/ers329.

Van Bockhaven, J., L.Spíchal, O.Novák, M.Strnad, T.Asano and S. Kikuchi, 2015. Silicon induces resistance to the brown spot fungus Cochliobolus miyabeanus by preventing the pathogen from hijacking the rice ethylene pathway. New Phytol., 206, 761-773.

Vivancos, J., C. Labbe, J. G. Menzies, and R. R. Belanger, 2015. Silicon-mediated resistance of Arabidopsis against powdery mildew involves mechanisms other than the salicylic acid SAdependent defense pathway. Mol. Plant Pathol. 16, 572-582.

Wallace, A. 1993. Participation of silicon in cation-anion balance as a possible mechanism for aluminum and iron tolerance in some Gramineae. Journal of Plant Nutrition. 16:547-553.

Wang, Y., A.Stass, and W. J. Horst, 2004. Apoplastic binding of aluminum is involved in siliconinduced amelioration of aluminum toxicity in maize. Plant Physiol. 136, 3762-3770.

Wonisch, H., F.Gérard, M.Dietzel, J.Jaffrain, O.Nestroy and J.P. Boudot, 2008. Occurrence of polymerized silicic acid and aluminum species in two forest soil solutions with different acidity. Geoderma, 144:435-445.

Worrall, D., G. H.Holroyd, J. P. Moore, M.Glowacz, P. Croft, J. E.Taylor, et al. 2012. Treating seeds with activators of plant defence generates long-lasting priming of resistance to pests and pathogens. New Phytol. 193, 770-778.

Yamamoto, Y., Y. Kobayashi, S. R. Devi, S. Rikiishi, and H. Matsumoto, 2003. Oxidative stress triggered by aluminum in plant roots. Plant Soil 255, 239-243.

Ye, M., Y. Song, J. Long, R. Wang, S. R. Baerson, Z. Pan, et al., 2013. Priming of jasmonatemediated antiherbivore defense responses in rice by silicon. Proc. Natl. Acad. Sci. U.S.A. 110, E3631-E3639.

Zhang, G., Y. Cui, X. Ding and Q. Dai, 2013. Stimulation of phenolic metabolism by silicon contributes to rice resistance to sheath blight. J. Plant Nutr. Soil Sci., 176, 118-124. doi: 10.1002/jpln.201200008

Zsoldos, F., A. Vashegyi, A. Pecsvaradi, and L. Bona, 2003. Influence of silicon on aluminium toxicity in common and durum wheats. Agronomie, 23, 349-354. 